Changes in macrofaunal biological traits across estuarine gradients : implications for the coastal nutrient filter

\title{
Villnäs, Anna
}

2019-07-18

Villnäs , A , Janas , U , Josefson , A B , Kendzierska , H , Nygård , H , Norkko , J \& Norkko , A 2019 , ' Changes in macrofaunal biological traits across estuarine gradients : implications for the coastal nutrient filter ' , Marine Ecology. Progress Series , vol. 622 , pp. 31-48 . https://doi.org/10.3354/meps1

http://hdl.handle.net/10138/317799

https://doi.org/10.3354/meps 13008

acceptedVersion

Downloaded from Helda, University of Helsinki institutional repository.

This is an electronic reprint of the original article.

This reprint may differ from the original in pagination and typographic detail.

Please cite the original version. 
1 Changes in macrofaunal biological traits across estuarine gradients - implications for the

2

3

4 Running head: Macrofaunal traits affect the coastal filter

Norkko $^{1}$, Alf Norkko ${ }^{1,5}$

8

$9 \quad{ }^{1}$ Tvärminne Zoological Station, University of Helsinki, FI-10900 Hanko, Finland

$10 \quad{ }^{2}$ Institute of Oceanography, University of Gdansk, PL-81-378 Gdynia, Poland

$11{ }^{3}$ Department of Bioscience, Aarhus University, DEK-4000 Roskilde, Denmark

$12{ }^{4}$ Finnish Environment Institute, SYKE, Marine Research Centre, FI-00790 Helsinki, Finland

$13 \quad{ }^{5}$ Baltic Sea Centre, Stockholm University, SE-10691 Stockholm, Sweden

14

15 Corresponding author: Anna Villnäs

16 e-mail address: anna.villnas@ helsinki.fi

17 Postal address: Tvärminne Zoological Station, University of Helsinki, J.A. Palménin tie 260, FI-

1810900 Hanko, Finland

19

20

21 
2 Benthic macrofaunal communities have a profound impact on organic matter turnover and nutrient

3 cycling in marine sediments. Their activities are of particular importance in the coastal filter, where

4 nutrients and organic matter from land are transformed and/or retained before reaching the open

5 sea. The benthic fauna modify the coastal filter directly (through consumption, respiration,

6 excretion and biomass production) and indirectly (through bioturbation). It is hard to experimentally

7 quantify faunal contribution to the coastal filter over large spatial and temporal scales that

8 encompass significant environmental and biological heterogeneity. However, estimates can be

9 obtained with biological trait analyses. By using benthic biological traits, we explore how the

10 potential contribution of macrofaunal communities to the coastal filter differ between inner and

11 outer sites in an extensive archipelago area, and examine the generality of the observed pattern across contrasting coastal areas of the entire Baltic Sea. Estimates of benthic bioturbation, longevity and size (i.e. "stability") and total energy- and nutrient contents differed between coastal areas and inner versus outer sites. Benthic traits indicative of an enhanced nutrient turnover but a decreased capacity for temporal nutrient retention dominated inner sites, while outer sites were often dominated by larger individuals, exhibiting traits that are likely to enhance nutrient uptake and retention. The overarching similarities in benthic trait expression between more eutrophied inner $v s$ less affected outer coastal sites across the Baltic Sea suggest that benthic communities might contribute in a similar manner to nutrient recycling and retention in the coastal filter over large geographical scales.

\section{Key words:}

benthic communities, coastal filter, biological traits, nutrient cycling, Baltic Sea 


\section{INTRODUCTION}

2 Coastal and estuarine ecosystems receive increasing amounts of organic material and nutrients as a

3 consequence of accelerating human settlement and activities along the world's coastal margins

4 (Nixon 1995, Cloern et al. 2016). By transforming, retaining or removing nutrients entering the sea

5 from land, the coastal ecosystems can, through a range of biogeochemical processes, function as a

6 filter and alleviate the anthropogenic pressure on the sea (Asmala et al. 2017). The capacity of the coastal ecosystem to buffer eutrophication is influenced by physical attributes (e.g. catchment area, land runoff, basin size, topography and hydro-morphology) that together determine the water residence time of the system. The residence time, together with light conditions will in turn influence rates of sedimentation, degradation and biological uptake (i.e. primary and secondary production) of nutrients and organic material along the land-to-sea continuum (Elliot \& Whitfield 2011). These processes will successively alter the quantity and quality of organic matter and nutrients that reach the open sea (Josefson \& Rasmussen 2000, Asmala et al. 2016). ecosystem (Nixon 1995), there is a more limited understanding regarding how the biota contributes to the system's filtering capacity (but see Sundbäck et al. 2003, McGlathery et al. 2007, Lloret \& Marín 2011). Several studies suggest that most of the nutrients that enter coastal ecosystems are eutrophic coastal waters are often characterized by a rapid proliferation of fast growing ephemeral algae (Sundbäck et al. 2003). In coastal areas, mineralization of the produced organic matter is suggested to mainly occur at the seafloor (Hietanen et al. 2007, Hellemann et al. 2017), since the close connection between the pelagic and benthic realm (benthic-pelagic coupling; Griffiths et al. 2017) makes the sediment serve as a site for organic matter retention and transformation.

Consequently, the filtering capacity of coastal areas is likely to be substantially influenced by activities of benthic faunal communities (Josefson \& Rasmussen 2000, Allgeier et al. 2017). For 
example, results by Josefson \& Rasmussen (2000) indicate that a major part of primary production in shallow estuaries can be consumed by the benthic fauna and their findings suggest that the benthic standing stock might even be food limited. Through ingestion, egestion, production and excretion, the animals regenerate the consumed nutrients (Hall et al. 2007, Vanni et al. 2013) and will thus have a considerable impact on the overall turnover of carbon and nutrients in the coastal filter.

The potential of animals to directly influence the turnover of carbon and nutrients largely depends on their allometric (i.e. size-dependent) and stoichiometric traits (i.e. the elemental content and ratios of a species, here focusing on carbon, nitrogen and phosphorous). Animals that have a small biomass often have higher rates of metabolism and respiration compared to larger ones, which might result in a higher mass-specific nutrient excretion rate for smaller individuals (Brown et al. 2004, Hall et al. 2007). Consequently, when total biomass is equal, this suggests that there could be a higher nutrient flux from a community dominated by small animals than from a community dominated by large ones (Hall et al. 2007). In addition, the mass production of an individual scales positively with size, but mortality rates express an inverse size-relationship (Brown et al. 2004). As animal tissues often have higher nutrient concentrations compared to the surrounding environment (Vanni et al. 2013, Allgeier et al. 2017) this indicates that large, long-lived animals potentially can retain significant nutrient pools (cf. Atkinson \& Vaughn 2015) in comparison to more short-lived animals of small size.

The benthic fauna also affect sediment carbon and nutrient turnover indirectly. Through feeding they modify standing stocks, distribution and activity of primary producers and microbes, which often results in an enhanced decomposition of sediment organic matter (Hall et al. 2007). By bioturbating the sediment (i.e. by modifying the sediment through particle reworking and burrow ventilation; Queirós et al. 2013) the animals can stimulate aerobic respiration and thus increase organic matter mineralization rates, i.e. the decomposition of organic matter into nutrients (Welsh 
2003). In contrast, certain species have been observed to create a build-up of organic matter in deeper sediment layers, by functioning as a vector of fresh material into sub-surface layers which is likely to decrease mineralization rates (Josefson et al. 2012). Still, by bioturbating the sediment and by expanding the oxic-anoxic interface, the benthic fauna create suitable conditions for nitrifying and denitrifying bacteria, which promotes the cycling or removal of particulate organic nitrogen from the system. Bioturbating fauna can also enhance the sediment phosphorus retention capacity, as oxygenated sediments more readily absorb $\mathrm{P}$ to Fe compounds (Hietanen et al. 2007). Hence, the availability of land-derived nutrients will be reduced by direct or indirect transformations by the benthic fauna, gradually decreasing their biological availability and resulting in forms that are more susceptible to removal (i.e. $\mathrm{N}_{2}$ ) or permanent burial (e.g. organic or Fe-bound phosphorous; Asmala et al. 2017).

The contribution of benthic communities to the coastal filter is difficult to assess, as the coastal zone constitutes a highly dynamic and heterogeneous environment, with strong influences from land as well as the open sea which will vary according to season (Kauppi et al. 2017). This causes strong physico-chemical variation and heterogeneous habitats with differing sediment properties, to which the benthic communities have to adapt (Elliott \& Whitfield 2011). Along the freshwater to marine gradient from land towards the open sea, species diversity and abundance are known to change, as the number of fresh-water and estuarine species declines while the number of marine species increases (Remane 1934, Attrill 2002, Attrill \& Rundle 2002, Bierschenk et al. 2017). However, this pattern is far from static, as disturbance in form of land-derived nutrients resulting in organic matter enrichment will affect the benthic communities across the land-to sea continuum (Villnäs et al. 2018). The benthic response to organic enrichment and its subsequent stressors (e.g. hypoxia, $\mathrm{H}_{2} \mathrm{~S}$ ) has been shown to follow a successional degradation pattern (Leppäkoski 1975, Pearson \& Rosenberg 1978, Rhoads et al. 1978), where the initial stimulatory effects due to the increasing food supply are replaced by community degradation as eutrophication 
advances. Sensitive species are replaced by tolerant ones, and at advanced stages of eutrophication, homogenous, low-diverse communities with few functions and rapid turnover rates will dominate, and these are likely to impoverish the efficiency of the coastal filter. It is clear that an evaluation of benthic faunal contribution to the coastal filter needs to be based on common benthic features that allows a direct comparison of diverging communities, such as the biological traits and functions that are shared by different benthic organisms (Bremner et al. 2006, Snelgrove et al. 2018, Bierschenk et al. 2017).

In this study, we a) explore how benthic infaunal traits, documented to impact sediment carbon and nutrient cycling, change across a gradient from inner to outer coastal sites that differ in eutrophication status, and b) seek to identify commonalities in benthic infaunal trait expression within the coastal filter, by performing unique cross-system comparisons over a Baltic Sea wide scale. We identify subsets of traits that describe three essential properties (i.e. bioturbation, stability and elemental composition as represented by the content of energy and nutrients; Table 1) of the benthic community that can have profound implications for nutrient transformation (recycling by animals), removal (denitrification) and retention (binding of phosphate) in the coastal filter (Table 2). As the shallower, inner coastal sites included in this study have higher nutrient loading than outer ones (e.g. Flindt et al. 1997, Hänninen et al. 2000, Andrulewicz et al. 2004), we follow Pearson \& Rosenberg's paradigm (1978) hypothesizing that benthic communities at inner sites will be dominated by small, short-lived individuals that are primarily bioturbating the uppermost sediment layers and therefor enhance turnover rates of carbon and nutrients in the sediment (Table 2). Outer deeper sites, less prone to eutrophication are hypothesized to be dominated by larger, long-lived and deep-burrowing individuals that may have a higher contribution to the overall nutrient retention and removal capacity of the sediments (Table 2). We focus on an example area, the Tvärminne archipelago (northern Baltic Sea), but also explore the generality of our findings by utilizing data available from four additional coastal areas in the Baltic Sea (i.e. the Roskilde- 
1 Isefjord, Denmark, the Gulf of Gdansk, Poland and the St. Anna and Umeå archipelago, Sweden).

2 The areas represent estuaries (defined as partially enclosed water bodies, affected by both saline water from the sea and fresh water from rivers, land runoff and seepage; Conley et al. 2000) and archipelagos along the northwards gradient of decreasing salinity. These fjord-like systems have been found to be essential sites of nutrient removal in the Baltic Sea (Asmala et al. 2017).

\section{MATERIAL AND METHODS}

\subsection{Coastal areas}

The Tvärminne archipelago (TA) is located in the Gulf of Finland, at the southern end of the Hanko peninsula, NE Baltic Sea. This region is characterized by an irregular coastline and an extensive archipelago. The area is non-tidal, with surface water salinity varying between 5 and 7 (Table 3). The area receives freshwater outflow from the river Karjaanjoki, which is connected to a fjord-like inlet (Pojo Bay), which is separated from the inner archipelago by a $6 \mathrm{~m}$ deep sill. There are sharp 
Isefjord (Table 3), but the water is usually well mixed and thus well oxygenated. Along the Roskilde Fjord, there is a distinct nutrient gradient with higher nutrient concentrations in the inner parts, decreasing towards the outer areas of the fjord (Flindt et al. 1997), while even lower nutrient concentrations are noted for the Isefjord (Josefson \& Hansen 2004). Soft sediment, varying from sand to fine silt and mud covers the seafloor.

The Gulf of Gdansk (GG) is situated in the eastern part of the southern Baltic Sea. It encompasses the Puck Lagoon, which is a shallow (on average $4.8 \mathrm{~m}$ ), sandy, semi-enclosed water body that is separated from the outer Puck Bay by a periodically submerged sandbar. The coastal areas of the outer Puck Bay are partly sheltered from open sea waters by the Hel Peninsula. These areas have, in general, a longer water residence time than the corresponding depth stratum in the open sea, and are also more affected by eutrophication (Table 3, Andrulewicz et al. 2004). The Gulf of Gdansk is significantly deeper (on average $59 \mathrm{~m}$ ) and receive large inflows from the Vistula river (Kruk-Dowgiałło \& Szaniawska 2008) that cause seasonal salinity and temperature stratifications. Surface water salinity in the basin is around 7.5. The soft-bottom sediments in the Gulf encompass sand, silty sand and mud (Uscinowicz 2011, Thoms et al. 2018).

The St. Anna archipelago (St. A) is situated south of Stockholm, in the northern part of the Baltic Proper. This archipelago area is relatively shallow with highly varying bottom topography (depth ranges between $<10$ to $60 \mathrm{~m}$ ). Its northwestern inner basins (Slätbaken and Trännöfjärden) receive freshwater discharge from the river Söderköpingsån that has a catchment area of $880 \mathrm{~km}^{2}$. A substantial part of its drainage area $(26 \%)$ is dominated by farmland and hence the nutrient inputs can occasionally be high (Arheimer et al. 2015). The water exchange in the inner sub-basins is restricted by sills (Slätbaken) or by the dense archipelago (Trännöfjärden), resulting in an accumulation of organic matter on the seafloor and occasional occurrence of oxygen deficiency (Persson \& Jonsson 2000). This also creates a gradient of decreasing nutrient concentrations from inner areas towards the open sea (Arheimer et al. 2015). The outer part in the St. Anna archipelago, 
1 Kärrfjärden, has a complex topography, and is sheltered from the open sea by a dense cluster of islands (Karlsson et al. 2010). The salinity in St. Anna archipelago ranges between 3 to 6 (Table 3). Umeå archipelago (UA) receives freshwater discharge from the Ume and Vindel Rivers,

4 which together have a drainage area of $26814 \mathrm{~km}^{2}$, dominated by forest, mountains as well as

5 farming areas. The freshwater discharges mainly to Österfjärden and further into Fjärdgrunds-

6 området. Österfjärden is a shallow, almost enclosed basin with a longer water residence time than

7 the outer areas (Table 3). It is connected to the outer Fjärdgrundsområdet archipelago and the outer

8 coastal waters of the Quark. Both basins are quite shallow $(<30 \mathrm{~m})$ and dominated by soft

9 sediments. The inner basin is considered to be moderately affected by eutrophication, while the 10 outer basin has a good eutrophication status. The salinity is low, ranging from 2 in inner parts to 4.5 11 in outer areas, and this region can have ice for more than 150 days per year (Table 3 ).

\subsection{Data}

From the Tvärminne archipelago, monitoring data regarding benthic faunal composition

(individuals per $\mathrm{m}^{-2}$ ) as well as biomass (blotted wet weight, wwt $\mathrm{g} \mathrm{m}^{-2}$ ) from 38 sites along a transect from the inner, sheltered archipelago towards more exposed sites (Fig. 1) was available from the HERTTA database, Finnish Environment Institute (Table 3). All included sites have been sampled with a Van Veen grab sampler $\left(0.1 \mathrm{~m}^{2}\right)$ in August 2012, and sieved through a $1 \mathrm{~mm}$ mesh. In addition, GPS coordinates (decimal degrees), depth, bottom water salinity, organic matter content (loss on ignition, \%) and oxygen concentration ( $\mathrm{ml} / \mathrm{l}$ and \%) were available from the same sampling occasion at each site. The other coastal areas along the Baltic Sea salinity gradient were selected as comparable benthic community data was available from their sampling sites, i.e. identical sampling gears and methods of extraction had been used (Van Veen grab, $1 \mathrm{~mm}$ mesh size). However, there 
were temporal differences between the data sets, as the samplings were performed in different years as well as seasons (Table 3).

\subsection{Separation of inner versus outer coastal sites}

5 The number of sampled sites differed between areas, but generally represented a transect from

inner, sheltered towards more exposed sites, encompassing a depth range of 2 to $60 \mathrm{~m}$ (Fig. 1, Table 3). In the Tvärminne archipelago, the separation between inner versus outer sites followed the water body formations identified for the Water Framework directive, distinguishing between southwestern inner and outer archipelago sites (Perus et al. 2004). A Principal Component Analysis (PCA), based on geographic position $\left({ }^{\circ} \mathrm{N}\right.$; distance from main river discharge), wind-wave exposure and bottomwater salinity (Fig. S1), illustrate the environmental transect (Fig. S1). The environmental variables were normalized prior to calculation of Euclidean distances between sites. Also in the other coastal areas, the separation between inner and outer sites was based on available literature; sites in the Roskilde Fjord were considered to represent inner coastal sites, while sites in the outer Isefjord, outside the mouth of Roskilde Fjord, were classified as outer sites following Josefson \& Hansen (2004). Separation of inner and outer sites in the Gulf of Gdansk followed Andrulewicz et al. (2004). The separation of inner versus outer coastal sites in the St. Anna and Umeå archipelagos followed the water-body types established for the Water Framework Directive (WFD), a separation which is mainly based on salinity, stratification (based on buoyancy-frequency and mean salinity in surface versus bottom waters), and wave exposure (Hansson \& Håkansson 2004). In general, all inner sites were shallower, had lower salinity and were more eutrophied compared to their corresponding outer sites (Table 3). 


\subsection{Benthic biological traits}

2 Subsets of benthic biological traits considered important for affecting sediment nutrient cycling and

3 retention were selected to describe (1) bioturbation, (2) community stability, and (3) estimates of

4 species-specific content of energy and primary bioelements (i.e. carbon $(\mathrm{C})$, nitrogen $(\mathrm{N})$ and

5 phosphorus (P); Table 1). The size, environmental position and reworking mode of benthic species

6 were considered as essential traits for describing bioturbation, while longevity, together with size,

7 were chosen to depict the stability of the community (Table 1,2). We assigned species to the trait

8 modalities using published classifications as well as taxonomic and morphologic sources of

9 information (Fish \& Fish 1996, MarLIN 2006, Queirós et al. 2013, Villnäs et al. 2018, Polytraits

10 Team 2019) and applied the fuzzy coding procedure if a species was considered to express several

11 modalities (Chevenet et al. 1994), summing up to 1 within a trait. The fuzzy coded trait expressions

12 of individual species were scaled up by correcting each modality for species- and sample specific abundances, creating a site-by-trait matrix. Abundance was used as a correction factor instead of biomass, as we did not have information about the size-distribution of the individuals. However, for establishing species-specific energy content ( $\mathrm{kJ}$ per individual), energy proxies ( $\mathrm{kJ}$ per $\mathrm{g}$ wwt) were obtained (Weigel et al. 2016) or calculated for each species following biometric conversion factors (Rumohr et al. 1987, Brey 2001). Species-specific CNP-contents (\% per g dry weight) were available from the Tvärminne area (Villnäs et al. unpublished) and from the literature (e.g. Brey 2001, Liess \& Hillebrand 2005, Brey et al. 2010). In cases where there were no species-specific data available, we applied the values of the closest taxonomic level. To estimate the energy and CNP (E_CNP) content for one individual of a species, the content was recalculated for the average wet weight of a species at a site. The carbon, nitrogen and phosphorus contents of the species were highly positively correlated $\left(\mathrm{R}^{2}>0.8, \mathrm{p}<0.0001\right)$ and thus considered as one trait. The energy and CNP content of the species was divided into three trait categories, describing a low, medium and high content, based on log-transformed distributions (Table 1, 2, Fig. 2). For the Roskilde Fjord, 
1 information regarding $\mathrm{C}, \mathrm{N}, \mathrm{P}$ content of the benthic fauna was not available, and therefore excluded from the statistical analyses.

Traits were grouped within a subset (cf. Villnäs et al. 2018) for graphical illustrations.

4 For bioturbation the traits grouped within a subset described; 1) no transport, 2) epibenthic surface

5 modifiers, 3) small tube dwellers or 4) biodiffusers in the uppermost sediment layers, 5) large

6 biodiffusers in deeper sediment layers, and 6) medium sized gallery diffusers. To describe stability,

7 the traits were grouped to describe 1) small, short-lived species, 2) medium-sized species with a

8 life-span of 2-5 years and 3) large, long-lived species (5-10 years or more). Species' energy and

9 nutrient contents were divided into 1) low, 2) medium and 3) high (cf. Fig. 2). The subsets were

10 related to processes and functions that could enhance nutrient retention and removal from the

11 coastal filter based on literature sources (Table 2), but due to the lack of data, this study does not consider remineralization rates or fluxes of nutrients across the sediment water interface.

\subsection{Statistical analyses}

Differences in benthic community abundance, biomass and trait subsets between coastal areas and inner versus outer sites were explored with multivariate analyses (PRIMER). Non-parametric multidimensional scaling (nMDS) was used for initial examination of spatial patterns. Differences between areas and inner and outer sites were further analyzed with two-way crossed analyses of similarities (ANOSIM), while one-way ANOSIM was used to distinguish divergences in trait composition between sites within an area. ANOSIM is a non-parametric permutation procedure that compare rank similarities among samples within and between sites based on the underlying similarity matrix (calculated with the Bray-Curtis measure). The test statistic, R, represent well separated sites when $\mathrm{R}>0.75$, overlapping but clearly different sites $0.75>R>0.5$, while $R<0.25$ represents sites that are barely separable at all (Clarke \& Gorley 2001). The significance level is 
1 obtained by referring the observed value of $\mathrm{R}$ to its permutation distribution (Clarke et al. 2014).

2 The SIMPER procedure was used to identify the species contributing to (dis)similarities within and between sites.

4 To illustrate how the benthic trait composition changed from inner towards outer sites of a coastal

5 area, we used a principal coordinates analysis (PCO) to project the variation between the sites in multivariate space onto principal coordinate axes, and performed this analysis for each trait subset

7 (describing bioturbation mode, energy and nutrient content and stability). The PCO values of the

8 axis explaining the largest part of variation were plotted for each coastal area, sorting the sites

9 according to their distance to the main source of freshwater discharge (as visually estimated by

10 inspecting their geographic position) to illustrate changes in trait composition between inner and outer sites (cf. Andersen et al. 2009). Instead of a PCO, a constrained analysis, CAP (canonical analysis of principal coordinates) was used for the Umeå archipelago to find axes through the multivariate cloud of points that best discriminated among the a priori groups (i.e. inner $v s$ outer sites). CAP can be used in cases when the direction through the data cloud that distinguishes the sites from one another is different from the direction of greatest variation across the data cloud (Anderson et al. 2008). The Bray-Curtis measure, underlying both the PCO and CAP analyses, was based on fourth root transformed abundance, biomass and trait data in order to down-weigh the importance of dominating species. The analyses were performed with the PRIMER 7 software and PERMANOVA+ (Anderson et al. 2008, Clarke et al. 2014, Clarke \& Gorley 2015). Complementing the PCO plots, the trait groups within a subset (cf. Villnäs et al. 2018) were used to illustrate the main changes in trait composition at each site in a stacked column chart. A majority of individuals ( $>98 \%$ ) could be assigned to the identified trait groups (Villnäs et al. 2018). 


\section{RESULTS}

\subsection{Tvärminne archipelago}

For the Tvärminne archipelago, there was an overlapping but clear difference between inner and outer sites regarding benthic community composition (abundance), while a less clear difference for biomass was observed (Table 4). The bivalve, Macoma balthica, the spionid polychaete Marenzelleria spp., Chironomidae as well as Hydrobiidae dominated inner sites, while the crustacean, Monoporeia affinis was abundant at outer sites (Table S1).

The difference in community composition between inner and outer sites was reflected in the overall trait composition of the benthic communities (Table 4). There was an overlapping but clear difference between inner and outer sites for the subset of traits describing benthic bioturbation (ANOSIM R=0.45, p=0.0001, Fig. 3A). The inner sites had high prevalence of very small and small, epibenthic surface modifiers and tube dwellers, while the outer sites had higher numbers of biodiffusers in the top sediment layer. Biodiffusers in deeper parts of the sediment were abundant at all sites together with gallery diffusers (Fig. 3A). The subset of traits describing the stability of the benthic community also showed differences between inner and outer sites (ANOSIM R=0.427, $\mathrm{p}=0.0001$, Fig. 3B). Short-lived, small individuals were generally more abundant at inner coastal sites, while medium-sized individuals with a life span of 2-5 years were more dominant at the outer sites. However, only small differences between sites were observed for large, long-lived individuals (Fig. 3B). Regarding traits describing energy- and CNP content, we found that individuals having low energy and nutrient contents were slightly more abundant at inner sites compared to the outer ones, but the sites could barely be separated (Fig 3C; ANOSIM: R=0.23, p=0.0004). 


\subsection{Comparing spatial variation in benthic community composition across coastal locations}

2 The number of species and diversity (H') decreased from the southern (RF) to the northern (UA)

3 coastal areas of the Baltic Sea, reflecting the gradient of decreasing salinity (Fig. S2). Overall, there

4 were overlapping but clear differences in benthic community abundance and biomass composition

5 between coastal areas as well as between inner and outer sites (Table 4). The variability in benthic

6 faunal abundance and biomass within an area was generally high. In the Roskilde Fjord, the within-

7 site similarities in benthic community composition for inner and outer sites were low $(<30 \%)$, due

8 to that different species of bivalves and polychaetes dominated different stations along the land to

9 sea gradient, but inner versus outer sites were well separated (Table 4, S1). In the Gulf of Gdansk,

10 gastropods belonging to Hydrobiidae, the polychaete Hediste diversicolor and the bivalve Macoma

11 balthica dominated the community at inner sites, while the crustaceans Pontoporeia femorata and

Diastylis rathkei were more common at outer sites (Table S1). Macoma balthica and Marenzelleria spp. were the dominant taxa of both inner and outer sites in the coastal areas of the northern Baltic Sea (i.e. the St. Anna, Tvärminne, and Umeå archipelagos), and often contributed to $70 \%$ of withinsite similarities (Table S1).

\subsection{Large-scale differences in benthic biological traits}

The overall trait composition was overlapping but differed, in general, both between coastal areas as well as between inner and outer sites (Table 4). However, the differences were not as marked as for abundance and biomass, indicating that using traits smoothed out the variation between the areas and enabled a comparison of differing community functions across this broad geographical scale.

Benthic bioturbation mode: Traits describing benthic bioturbation showed overlapping but clear differences between coastal areas $(\mathrm{R}=0.50, \mathrm{p}=0.0001)$, and between inner and outer sites $(\mathrm{R}=0.45$, $\mathrm{p}=0.0001$; two-way crossed ANOSIM). While gallery diffusers, tube dwellers and biodiffusers in 
upper sediment layers were dominant in the Roskilde Fjord, epibenthic surface modifiers and biodiffusers in deeper sediment layers played a more important role in the Gulf of Gdansk.

Similarly to the Tvärminne archipelago, biodiffusers and gallery diffusers in deeper sediment layers contributed most to the overall abundance in the St. Anna and Umeå archipelagos (Fig. 3A, 4).

For each coastal area, overlapping gradual shifts in bioturbation mode were observed from inner towards outer sites $(\mathrm{R}>0.3, \mathrm{p}<0.05$, Fig. 4$)$. When exploring traits contributing to dissimilarities between inner and outer sites, epibenthic surface modifiers and tube dwellers were often found to have more prominent roles at inner sites, while biodiffusers in the uppermost sediment layers were more common at the outer sites, especially in Roskilde Fjord and in the Gulf of Gdansk (Fig. 4). Biodiffusers in the deeper parts of the sediment were more abundant in the outer parts of Puck Bay, St. Anna and Umeå archipelago, but minor differences between sites were observed in the Roskilde Fjord. Gallery diffusers were in general present at all sites, but their higher occurrence in outer, or deeper, sites in the Roskilde Fjord and Umeå archipelago contributed to strengthen between-site dissimilarities in these areas (Fig. 4).

Stability: Also for traits representing community stability (i.e. maximum individual size and lifespan), overlapping but clear differences were observed between areas (two-way crossed ANOSIM $\mathrm{R}=0.50, \mathrm{p}=0.0001)$ and inner $v s$ outer sites $(\mathrm{R}=0.43, \mathrm{p}<0.0001)$. Short-lived, small individuals were generally more abundant at inner coastal sites in all areas, while medium-sized individuals with a life span of 2-5 years as well as large, long-lived individuals were more dominant at outer sites (Fig. 5). In the Roskilde Fjord, however, the innermost sites had extremely high abundances due to a dominance of small, short-lived individuals, but these sites also had a presence of large, long-lived ones. Still, medium-sized individuals with a lifespan of 2-5 y dominated outer sites also in this area (Fig. 5). The differences in traits depicting stability were significant between inner and outer sites for all areas $(\mathrm{R}>0.4, \mathrm{p}<0.01)$, except for the Roskilde Fjord $(\mathrm{p}>0.05)$. 
1 Energy and nutrient content: Overall, two-way crossed ANOSIM showed larger differences in

2 benthic energy content between areas $(\mathrm{R}=0.45, \mathrm{p}=0.0001)$ than between inner versus outer sites

$3(\mathrm{R}=0.22, \mathrm{p}=0.0008)$. In general, individuals with low energy content dominated in the Roskilde

4 Fjord and Gulf of Gdansk, while those with medium energy content were more abundant in the

5 Tvärminne, St. Anna and Umeå archipelagos (Fig. 3C). Although an increasing trend in the energy

6 and carbon, nitrogen and phosphorus (ECNP) content of benthic individuals was observed when

7 comparing inner versus outer sites in the Gulf of Gdansk, St. Anna and Umeå archipelago (R>0.35,

$8 \quad \mathrm{p}<0.01$; Fig. 6) the sites were not clearly separable. In Roskilde Fjord, inner sites were dominated

9 by individuals having low energy contents, while species with a medium energy content became more abundant towards outer sites, but this difference was non-significant ( $p>0.05$, Fig. 6).

\section{DISCUSSION}

We found high variability but still significant differences in benthic community and trait composition between different coastal areas of the Baltic Sea. Despite these differences, there were overarching similarities in functional traits important for influencing sediment carbon and nutrient cycling when comparing inner, shallow versus outer, often deeper sites. In accordance with our hypotheses we found that benthic communities at inner coastal sites more prone to eutrophication were likely to express traits that enhance turnover rates of carbon and nutrients (i.e. small, shortlived, epibenthic surface modifiers or tube dwellers that have low total energy and nutrient content per individual). In contrast, outer less nutrient enriched, deeper sites were dominated by species that could have a more prominent role for nutrient removal and retention in the coastal filter, as their expressed traits that can promote denitrification, sediment phosphate adsorption and temporal carbon and nutrient retention within animal tissue (Table 2). 
Both for the Tvärminne archipelago and for the other coastal areas, there was generally a higher presence of small, short-lived species with lower individual energy, carbon and nutrient content at inner compared to outer coastal sites. As metabolism scales allometrically with body mass, such species are likely to have higher metabolism (Brown et al. 2004), high carbon and nutrient content per mass unit and thus higher rates of excretion per mass unit compared to larger species (Hall et al. 2007). As excreted nutrients (often in the form of $\mathrm{NH}_{4}{ }^{+}$and $\mathrm{PO}_{4}{ }^{3-}$ ) are readily taken up by microbes and primary producers, these species constitute an important step in the recycling chain (Allgeier et al. 2017) within the coastal filter. Especially the presence of epibenthic surface modifiers, mostly grazers, at shallow, illuminated inner sites might have an important role for regulating microphytobenthic primary production (Miller et al. 1996, Norkko et al. 2010, Janas et al. 2019), while their contribution to sediment bioturbation is known to be marginal (Orvain et al. 2004). In contrast, the high abundance of tube dwellers at inner sites suggests efficient bioirrigation and an active incorporation of organic matter into the sediment. Tube dwellers, such as chironomids, have $\mathrm{u}$-shaped tubes and have been shown to stimulate a release of nutrients from the sediment to overlying water (Hansen et al. 1998), which enhances gross primary production as well as nutrient turnover rates in the system (Herren et al. 2017), possibly stimulating eutrophication. However, the influence of tube dwellers on sediment nutrient cycling is not straight-forward (Hölker et al. 2015), and depending on sediment quality and redox state, tube dwellers might temporary enhance nutrient removal from the system through enabling phosphorus binding and denitrification (Hansen et al. 1998, Hölker et al. 2015). Indeed, Benelli et al. (2018) showed that chironomid larvae and benthic algae in combination significantly decreased the internal nutrient recycling in a shallow coastal ecosystem and suggest that they could even control the pelagic production. Importantly, the authors also suggest that this effect could be temporary, as the burrows might turn anoxic when the chironomids become flying insects, and the adsorbed phosphorous could then potentially be regenerated to the water column (Hölker et al. 2015, Benelli et al. 2018). 
The benthic communities at outer coastal sites were often dominated by medium- to large

2 sized, relatively long-lived species with higher energy and nutrient content per individual and is therefore suggested to constitute a more stable nutrient pool. In addition, outer sites had, in general, a higher abundance of biodiffusers in upper and lower sediment layers, which is likely to promote nutrient retention and removal (Table 2). For example, the biodiffusing amphipods Monoporeia affinis and Pontoporeia femorata, which were common in several of the outer study sites, actively rework the sediment and enhances sediment oxygen penetration. Monoporeia affinis has been observed to increase denitrification rates as well as the amount of phosphate bound to the sediment (Karlson et al. 2007) and its activities are thus likely to increase the functionality of the coastal filter. A high abundance of gallery biodiffusers, such as Hediste diversicolor and Marenzelleria spp., observed both at inner and outer sites, is known to promote bacterial communities which will support organic matter mineralization rates and consequently, nutrient recycling. However, these gallery diffusers, although showing differences in burrow structure and bioirrigation modes (Kristensen et al. 2014), both increase sediment oxygenation and can probably promote sediment nutrient retention (through increased $\mathrm{P}$ binding) and removal (through denitrification) in the long term (Norkko \& Reed et al. 2012), which will enhance the efficiency of the coastal filter.

Interestingly, these two gallery diffusers have also been observed to be vectors of fresh organic material into deeper sediment layers (Nordström et al. 2006, Josefson et al. 2012, Kauppi et al. 2017) which is hypothesized to slow down overall mineralization rates and could also counteract oxygen depletion in bottom waters (Josefson et al. 2012).

The difference in benthic trait composition between inner versus outer sites observed in this study are likely to affect the efficiency of the coastal filter as described above. However, it is clear that the contribution of benthic invertebrates to sediment nutrient recycling and retention cannot be quantified based on trait classifications, and that the net effect of the animals will be contextdependent. Indeed, the impact of benthic macrofauna on sediment nutrient fluxes has been shown to 
vary across habitats (Gammal et al. 2019, Janas et al. 2019), due to disturbances (Villnäs et al. 2013), with season (Kauppi et al. 2017) and to have contrasting short versus long-term effects (Norkko \& Reed et al. 2012). In addition, trait modalities and groupings cannot be assumed to describe the exact performance of species. For example, Renz \& Foster (2013) showed clear differences in burrow morphology, depth and bioturbation capacity between the sibling species of Marenzelleria. Kristensen et al. (2014) in turn suggested that activities of the gallery diffusers Marenzelleria viridis and Arenicola marina, in contrast to Nereis diversicolor, would increase concentrations of dissolved incorganic nitrogen concentrations in bottom waters which would enhance pelagic primary production. Although more specific trait classifications could be adapted, the influence of species would still depend upon a range of environmental factors affecting both species behavior and biogeochemical processes, including for example food quantity and quality, predation pressure, sediment organic matter content and nutrient concentrations, redox state and nutrient concentrations in overlying waters. Indeed, Thoms et al. (2018) examined the impact of benthic macrofauna on the coastal filter function in the Gulf of Gdansk and suggested that coastal zones with a large numbers of deep-burrowing infaunal species, stimulating re-mineralization but also transforming nutrients into biomass, are likely to offer the best filter function, which supports the results of our study.

When interpreting the between-site comparisons in benthic trait distribution, it should be noted that the number of sampled stations differ between areas as well as sites. This will greatly affect the significance value of the ANOSIM analysis, while the R-value, which is not a function of the number of replicates, represents the absolute measure of the differences between sites in multidimensional space (Clarke and Gorley 2015). Nevertheless, the ANOSIM analyses supported the observed pattern of differences between inner and outer sites as shown by the Principal Coordinate Analyses, which was explaining a large part of the variation in multivariate trait-space, supporting the hypothesized between-site differences. Although our study could not relate variation 
1 in traits to environmental parameters due to a lack of environmental data, divergences were found

2 between inner versus outer sites for all the studied areas both in terms of hydrography and eutrophication pressure (Table 3). Villnäs et al. (2018) showed that such divergences, specifically in sediment organic matter content, temperature stratification of the water column, and bottom water salinity and oxygen content were able to explain a large part of the differences in benthic faunal bioturbation modes in the Tvärminne archipelago. In this study, we can only speculate why the difference in community trait composition occurs but some may be related to differences in eutrophication loading as well as water residence time. As indicated in Table 3 the inner sites in each coastal area have substantially longer residence time than the outer sites. In addition to a high nutrient input, long residence time allows the nutrients to circulate many times in the system of the inner sites before being flushed out, and may thus contribute to an even higher nutrient pressure. Long residence time/low flushing rates may also favor hypoxia/intermittent anoxia and allow small opportunists do dominate. In contrast, at the outer sites the flushing is higher and nutrients may have less time to circulate in the system before being transported to the open sea. At the same time, since flushing is higher, the risk of hypoxia is lower allowing species with longer life spans to dominate, and thereby increasing temporary retention. In addition, short residence time /high flushing may mean higher horizontal flux and thereby more food for suspension feeders, many of which attains large body size. Indeed, Lloret \& Marín (2011) illustrated that a benthic macroalgae (Caulerpa prolifera) together with benthic invertebrates could form an effective coastal filter in Mar Menor Lagoon, Mediterranean Sea. These authors showed that benthic species favoring higher nutrient turnover as well as resuspension were more abundant at shallow sites, close to the outlet of a wadi, while suspension feeders contributing to a net retention of nutrients were more abundant at outer, deeper sites (Lloret \& Marín 2011).

The comparable pattern in trait composition that distinguished inner versus outer sites 
similar manner to recycling and retention of the nutrient cocktail across coastal areas of the Baltic Sea. The observed dichotomy in benthic trait composition between inner and outer areas is important, as it indicates that these areas differ in nutrient processing mode and -capacity. The biological trait composition of the benthic communities at inner sites was indicative of an intensified carbon- and nutrient turnover, which could possibly promote the internal feedback to the eutrophication cycle. In contrast, traits important for slower turnover rates, enhancing retention (binding or burial) and removal (denitrification) were more abundant at outer sites, probably creating a more efficient nutrient filter. The differences in trait composition between inner versus outer sites highlights that disturbances such as eutrophication, which can homogenize benthic communities over larger spatial scale, could result in more rapid nutrient turnover rates and low retention of carbon and nutrients. This underlines the importance of preserving healthy benthic communities that can enhance the capacity of the ecosystem to cope with eutrophication. Thus, the preservation of benthic community structure and function will be vital in management efforts striving to sustain the functionality of our coastal seas.

\section{Acknowledgements}

We wish to thank Prof. Jacob Carstensen, Janus Larsen, Jan Albertsson and Pirkko Kauppila for help with compiling data and Johanna Gammal for help with ArcGIS. Parts of the data were collected within the MARMONI (Innovative approaches for marine biodiversity monitoring and assessment of conservation status of nature values in the Baltic Sea) project funded by the European Union LIFE+ Nature \& Biodiversity program (Project Nr. LIFE09 NAT/LV/000238), http://marmoni.balticseaportal.net. We thank our colleagues within the BONUS COCOA project for fruitful discussions regarding benthic biological traits. We are grateful to Tvärminne Zoological Station for providing excellent research facilities. 


\section{$1 \quad$ Funding}

2 This study was funded by the Sophie von Julins Stiftelse, the BONUS COCOA project, which was

3 supported by BONUS (Art 185) funded jointly by EU and the Academy of Finland (AN) and the

$4 \quad$ Academy of Finland (project ID 294853).

5

6

7 


\section{REFERENCES}

Allgeier JE, Burkepile DE, Layman CA (2017) Animal pee in the sea: consumer-mediated nutrient dynamics in the world's changing oceans. Global Change Biol 23: 2166-2178

Andersen TJ, Jensen KT, Lund-Hansen L, Mouritsen KN, Pejrup M (2002) Enhanced erodibility of fine-grained marine sediments by Hydrobia ulvae. J Sea Res 48: 51-58.

Anderson MJ, Gorley RN, Clarke KR (2008) PERMANOVA+ for PRIMER: Guide to software and statistical methods. PRIMER-E, Plymouth, UK.

Andrulewicz E, Kruk-Dowgiallo L, Osowiecki A (2004) An expert judgement approach to designating ecosystem typology and assessing the health of the Gulf of Gdansk. In Schernewski G and Löser N (eds.): Managing the Baltic Sea. Coastline Reports 2. The Coastal Union, Warnemünde, p 53-61.

Arheimer B, Nilsson J, Lindström G (2015) Experimenting with coupled hydro-ecological models to explore measure plans and water quality goals in a semi-enclosed Swedish bay. Water 7: 3906-3924.

Asmala E, Kaartokallio H, Carstensen J, Thomas DN (2016) Variation in riverine inputs affect dissolved organic matter characteristics throughout the estuarine gradient. Front Mar Sci 2:125. doi: 10.3389/fmars.2015.00125

Asmala E, Carstensen J, Conley DJ, Slomp CP, Stadmark J, Voss M (2017) Efficiency of the coastal filter: Nitrogen and phosphorus removal in the Baltic Sea. Limnol Oceanogr 62: S222S238.

Atkinson CL, Vaughn CC (2015) Biogeochemical hotspots: temporal and spatial scaling of the impact of freshwater mussels on ecosystem function. Freshw Biol 60: 563-574.

Attrill MJ (2002) A testable linear model for diversity trends in estuaries. J. Anim. Ecol. 71: 262269.

Attrill MJ, Rundle SD (2002). Ecotone or Ecocline: Ecological boundaries in estuaries. Est. Coast. Shelf Sci 55: 929-936.

Benelli S, Bartoli M, Zilius M, Vybernaite-Lubiene I, Ruginis T, Petkuviene J, Fano EA (2018) Microphytobenthos and chironomid larvae attenuate nutrient recycling in shallow-water sediments. Freshw Biol 63:187-201. 
Bierschenk AM, Savage C, Matthaei CD (2017) Intensity of catchment land use influences biological traits of benthic invertebrates along a freshwater-marine continuum. Limnol Oceanogr 62: S2929-S308.

Bremner J, Rogers SI, Frid CLJ (2006) Methods for describing ecological functioning of marine benthic assemblages using biological traits analysis (BTA). Ecol Ind 6: 609-622.

Brey T (2001) Population dynamics in benthic invertebrates. A virtual handbook. Version 01.2. http://www.thomas-brey.de Accessed 20.04.2018.

Brey T, Müller-Wiegmann C, Zittier Z, Hagen W (2010) Body composition in aquatic organisms - a global data bank of relationships between mass, element composition and energy content. J Sea Res 64: 334-340.

Brown JH, Gillooly JF, Allen AP, Savage VM, West GB (2004) Toward a metabolic theory of ecology. Ecology 85:1771-1789.

Chevenet F, Doledec S, Chessel D (1994) A fuzzy coding approach for the analysis of long-term ecological data. Freshw Biol 31: 295-309.

Clarke KR, Gorley RN (2001) PRIMER v5: User Manual/Tutorial. PRIMER-E, Plymouth, UK.

Clarke KR, Gorley RN, Somerfield PJ, Warwick RM (2014) Change in marine communities: an approach to statistical analysis and interpretation. Third edition. PRIMER-E, Plymouth, UK.

Clarke KR, Gorley RN (2015) PRIMERv7: User manual/ tutorial. PRIMER-E, Plymouth, UK.

Cloern JE, Abreu PC, Carstensen J, Chauvaud L, Elmgren R, Grall J, Greening H, Johansson JOR, Kahru M, Sherwood ET, Xu J, Yin K (2016) Human activities and climate variability drive fastpaced change across the world's estuarine-coastal ecosystems. Global Change Biol 22: 513-529.

Conley DJ, Kaas H, Mohlenberg F, Rasmussen B, Windolf J (2000) Characteristics of Danish estuaries. Estuaries 23: 820-837.

Elliott M, Whitfield AK (2011) Challenging paradigms in estuarine ecology and management. Estuar Coast Shelf Sci 94: 306e314.

Fish JD, Fish S (1996) A Student's Guide to the Seashore. Second edition. Cambridge University Press, Cambridge, Great Britain. 
Flindt MR, Kamp-Nielsen L, Marques JC, Pardal MA, Bocci M, Bendoricchio G, Salomonsen J, Nielsen SN, Jorgensen SE (1997). Description of the three shallow estuaries: Mondego River (Portugal), Roskilde Fjord (Denmark) and the Lagoon of Venice (Italy). Ecol Model 102: 17-31.

Gammal J, Järnström M, Bernard G, Norkko J, Norkko A (2019) Environmental context mediates biodiversity-ecosystem functioning relationships in coastal soft-sediment habitats. Ecosystems 22: $137-151$.

Griffiths JR, Kadin M, Nascimento FJA, Tamelander T, Törnroos A, Bonaglia S, Bonsdorff E, Buchert V, Gårdmark A, Järnström M, Kotta J, Lindegren M, Nordström M, Norkko A, Olsson J, Weigel B, Zydelis R, Bleckner T, Niiranen S, Winder M (2017) The importance of benthicpelagic coupling for marine ecosystem functioning in a changing world. Global Change Biol. 23: 2179-2196.

Hansen K, Mouridsen S, Kristensen E (1997). The impact of Chironomus plumosus larvae on organic matter decay and nutrient $(\mathrm{N}, \mathrm{P})$ exchange in a shallow eutrophic lake sediment following a phytoplankton sedimentation. Hydrobiologia 364: 65-74.

Hansen K, Kristensen E (1998) The impact of the polychaete Nereis diversicolor and enrichment with macroalgal (Chaetomorpha linum) detritus on benthic metabolism and nutrient dynamics in organic-poor and organic-rich sediment. J Exp Mar Biol Ecol 231: 201-223.

Hansson M, Håkansson B. 2004. Indelning av svenska övergångs- och kustvatten i typer enligt Ramdirektivet för Vatten. Rapport för SMHI, Dnr: 2002/1796/1933. In Swedish

Hall ROJ, Koch BJ, Marchall MC, Taylor BW, Tronstad LM (2007) How body size mediates the role of animals in nutrient cycling in aquatic ecosystems. In: Hildrew AG, Edmonds-Brown R, Raffaelli D (Eds.). Body size: the structure and function of aquatic ecosystems. Cambridge University Press. pp: 286-305.

Hellemann D, Tallberg P, Bartl I, Voss M, Hietanen S (2017) Denitrification in an oligotrophic estuary: a delayed sink for riverine nitrate. Mar Ecol Prog Ser 583: 63-80.

Henriksen K, Rasmussen MB, Jensen A (1983) Effect of bioturbation on microbial nitrogen transformations in the sediment and fluxes of ammonium and nitrate to the overlying water. Ecol Bull 35: 193-205.

Herren CM, Webert KC, Drake MD, Zanden MJV, Einarsson Á, Ives AR, Gratton C (2017) Positive feedback between chironomids and algae creates net mutualism between benthic primary consumers and producers. Ecology 98: 447-455. 
Hietanen S, Laine AO, Lukkari K (2007) The complex effects of the invasive polychaetes Marenzelleria spp. on benthic nutrient dynamics. J Exp Mar Biol Ecol 352: 89-102.

Holmberg R, Ranta E, Mettinen A, Suonpää A, Valtonen M (2015) Mustionjoen, Fiskarsinjoen Pohjanpitäjänlahden ja Tammisaaren merialueen yhteistarkkailun yhteenveto vuosilta 20102013. Länsi-Uudenmaan vesi ja ympäristö ry julkaisu 254. 124 p. In Finnish.

Hänninen J, Vuorinen I, Helminen H, Kirkkala T, Lehtilä K (2000) Trends and gradients in nutrient concentrations and loading in the Archipelago Sea, Northern Baltic, in 1970-1997. Est Coast Shelf Sci 50: 153-171.

Hölker F, Vanni MJ, Kuiper JJ, Meile C, Grossart H-P, Stief P, Adrian R, Lorke A, Dellwig O, Brand A, Hupfer M, Mooi WM, Nützmann G, Lewandowski J (2015) Tube-dwelling invertebrates: tiny ecosystem engineers have large effects in lake ecosystems. Ecol Monogr 85: $333-351$.

Janas U, Burska D, Kendzierska H, Pryputniewicz-Flis D, Łukawska-Matuszewska K (2019) Importance of benthic macrofauna and coastal biotopes for ecosystem functioning - Oxygen and nutrient fluxes in the coastal zone, Estuarine, Coastal and Shelf Science 225 https://doi.org/10.1016/j.ecss.2019.05.020

Josefson AB, Rasmussen B (2000) Nutrient retention by benthic macrofaunal biomass of Danish estuaries: Importance of nutrient load and residence time. Est Coast Shelf Sci 50: 205-216.

Josefson AB, Hansen JLS (2004) Species richness of benthic macrofauna in Danish estuaries and coastal areas. Glob Ecol Biogeogr 13: 273-288.

Josefson AB, Norkko J, Norkko A (2012) Burial and decomposition of plant pigments in surface sediments of the Baltic Sea: role of oxygen and benthic fauna. Mar Ecol Prog Ser 455: 33-49.

Karlson K, Bonsdorff E, Rosenberg R (2007) The impact of benthic macrofauna for nutrient fluxes from Baltic Sea sediments. AMBIO 36: 161-167.

Karlsson M, Malmaeus M, Rydin E, Jonsson P (2010) Bottenundersökningar i Upplands, Stockholms, Södermanlands och Östergötlands skärgårdar 2008-2009. IVL Rapport B1928. 100 p. In Swedish.

Kauppi L, Norkko J, Ikonen J, Norkko A (2017) Seasonal variability in ecosystem functions: quantifying the contribution of invasive species to nutrient cycling in coastal ecosystems. Mar Ecol Prog Ser 572: 193-207. 
Kristensen E, Delefosse M, Quintana CO, Flindt MR, Valdemarsen T (2014) Influence of benthic macrofauna community shifts on ecosystem functioning in shallow estuaries. Front Mar Sci doi: 10.3389/fmars.2014.00041

Kruk-Dowgiałło L, Szaniawska A (2008) Gulf of Gdańsk and Puck Bay. In: Schiewer U (Ed.) Ecology of Baltic coastal waters. Ecological Studies (Analysis and Synthesis) 197. Springer, Berlin, Heidelberg.

Leppäkoski E (1975). Assessment of the degree of pollution on the basis of macrozoobenthos in marine and brackish-water environments. Acta Academiae Aboensis B 35.90 p.

Liess A, Hillebrand H (2005) Stoichiometric variation in C:N, C:P, and N:P ratios of littoral benthic invertebrates. J North Am Benthol Soc 24: 256-269.

Lloret J, Marín A (2011) The contribution of benthic macrofauna to the nutrient filter in coastal lagoons. Mar Poll Bull 62: 2732-2740.

MarLIN, 2006. BIOTIC - Biological Traits Information Catalogue. Marine Life Information Network. Plymouth: Marine Biological Association of the United Kingdom. Accessed 31.01.2019. Available from www.marlin.ac.uk/biotic

McGlathery KJ, Sundbäck K, Anderson IC (2007) Eutrophication in shallow coastal bays and lagoons: the role of plants in the coastal filter. Mar Ecol Prog Ser 348: 1-18.

Michaud E, Desrosiers G, Mermillod-Blondin F, Sundby B, Stora G (2005) The functional group approach to bioturbation: The effects of biodiffusers and gallery-diffusers of the Macoma balthica community on sediment oxygen uptake. J Exp Mar Biol Ecol 326: 77- 88.

Michaud E, Desrosiers G, Mermillod-Blondin F, Sundby B, Stora G (2006) The functional group approach to bioturbation: II. The effects of the Macoma balthica community on fluxes of nutrients and dissolved organic carbon across the sediment-water interface. J Exp Mar Biol Ecol 337: 178-189.

Miller DC, Geider RJ, MacIntyre HL (1996) Microphytobenthos: The ecological role of the "Secret Garden" of unvegetated, shallow-water marine habitats. II. Role in sediment stability and shallow-water food webs. Estuaries 19: 202-212.

Nordström M, Bonsdorff E, Salovius S (2006) The impact of infauna (Nereis diversicolor and Saduria entomon) on the redistribution and biomass of macroalgae on marine soft bottoms. J Exp Mar Biol Ecol 333: 58-70. 
Norkko A, Hewitt JE, Thrush SF, Funnell GA (2001) Benthic-pelagic coupling and suspensionfeeding bivalves: Linking site-specific sediment flux and biodeposition to benthic community structure. Limnol Oceanogr 46: 2067-2072.

Norkko A, Rosenberg R, Thrush SF, Whitlatch RB (2006) Scale- and intensity-dependent disturbance determines the magnitude of opportunistic response. J Exp Mar Biol Ecol 330: 195207.

Norkko J \& Reed DC, Timmerman K, Norkko A, Gustafsson BG, Bonsdorff E, Slomp CP, Carstensen J, Conley DJ (2012) A welcome can of worms? Hypoxia mitigation by an invasive species. Global Change Biol 18: 422-434.

Norkko J, Norkko A, Thrush SF, Valanko S, Suurkuukka H (2010) Conditional responses to increasing scales of disturbance, and potential implications for threshold dynamics in softsediment communities. Mar Ecol Prog Ser 413: 253-266.

Norkko A, Villnäs A, Norkko J, Valanko S, Pilditch C (2013) Size matters: implications of the loss of large individuals for ecosystem function. Sci Rep $3: 2646$

Nixon SW (1995) Coastal marine eutrophication: a definition, social causes, and future concerns. Ophelia 41: 199-219.

Orvain F, Sauriau P-G, Sygut A, Joassard L, Le Hir P (2004) Interacting effects of Hydrobia ulvae bioturbation and microphytobenthos on the erodibility of mudflat sediments. Mar Ecol Prog Ser 278: 205-223.

Pearson TH, Rosenberg R (1978) Macrobenthic succession in relation to organic enrichment and pollution of the marine environment. Oceanogr Mar Biol 16: 229-311.

Perus J, Bäck S, Lax H-G, Westberg V, Kauppila P, Bonsdorff E (2004) Coastal marine zoobenthos as an ecological quality element: a test of environmental typology and the European Water Framework Directive. In: Schernewski G, Wielgat M (Eds.): Baltic Sea Typology. Coastline Reports 4, p. 27-38

Persson J, Jonsson P (2000) Historical development of laminated sediments - an approach to detect soft sediment ecosystem changes in the Baltic Sea. Mar Poll Bull 40: 122-134.

Polytraits Team 2019. Polytraits: A database on biological traits of polychaetes. LifewatchGreece, Hellenic Centre for Marine Research. Accessed on 2019-01-31. Available from http://polytraits.lifewatchgreece.eu. 
Queirós AM, Birchenough SNR, Bremner J, Godbold JA, Parker R, Romero-Ramirez A, Reiss H, Solan M, Somerfield PJ, Van Colen C, Van Hoey G, Widdicombe S (2013) A bioturbation classification of European marine infaunal invertebrates. Ecol Evol 3: 3958-3985.

Remane A (1934) Die Brackwasserfauna. Verh Dtsch Zool Ges 7: 34-74.

Reise K (1983) Biotic enrichment of intertidal sediments by experimental aggregates of the depositfeeding bivalve Macoma balthica. Mar Ecol Prog Ser 12: 229-236.

Renz JR, Foster S (2013) Are similar worms different? A comparative tracer study on bioturbation in the three sibling species Marenzelleria arctica, M. viridis, and M neglecta from the Baltic Sea. Limn Oceanogr 58: 2046-2058.

Rhoads DC, McCall PL, Yingst JY (1978) Disturbance and production on the estuarine seafloor. Am Sci 66: 577-586.

Rumohr H, Brey T, Ankar S (1987) A compilation of biometric conversion factors for benthic invertebrates of the Baltic Sea. The Baltic Marine Biologists Publication 9, 56 p.

Snelgrove PVR, Soetaert K, Solan M, Thrush S, Wei C-L, Danovaro R, Fulweiler RW, Kitazato H, Ingole B, Norkko A, Parkes RJ, Volkenborn N (2018) Global carbon cycling on a heterogeneous seafloor. TREE 33: 96-105.

Stief P, Hölker F (2006) Trait-mediated indirect effects of predatory fish on microbial mineralization in aquatic sediments. Ecology 87: 3152-3159.

Sundby B, Gobell C, Silverberg N (1992) The phosphorus cycle in coastal marine sediments. Limnol Oceanogr 37: 1129-1145.

Sundbäck K, Miles A (2000) Balance between denitrification and microalgal incorporation of nitrogen in microtidal sediments, NE Kattegatt. Aquat Microb Ecol 22: 291-300.

Sundbäck K, Miles A, Hulth S, Pihl L, Engström P, Selander E, Svenson A (2003) Importance of benthic nutrient regeneration during initiation of macroalgal blooms in shallow bays. Mar Ecol Prog Ser 246: 115-126.

Thoms F, Burmeister C, Dippner JW, Gogina M, Janas U, Kendzierska H, Liskow I, Voss M (2018) Impact of macrofaunal communities on the coastal filter function in Bay of Gdansk, Baltic Sea. Front. Mar. Sci. 5:201. doi: 10.3389/fmars.2018.00201 
1 Thrush S, Hewitt JE, Gibbs M, Lundquist C, Norkko A (2006) Functional role of large organisms in intertidal communities: community effects and ecosystem function. Ecosystems 9: 1029-1040.

Tuominen L, Mäkelä K, Lehtonen KK, Haahti H, Hietanen S, Kuparinen J (1999) Nutrient fluxes, porewater profiles and denitrificaiton in sediment influenced by algal sedimentation and bioturbation by Monoporeia affinis. Est Coast Shelf Sci 49: 83-97.

Uscinowicz S (2011) Surface sediments and sedimentation processes. p. 76-82 in: Geochemistry of Baltic Sea surface sediment. Uscinowicz S (Ed.). Polish Geological Institute-National Research Institute, Warsaw, Poland.

Van Colen C, Montserrat F, Vincx , Herman PMJ, Ysebaert T, Degraer S (2008) Macrobenthic recovery from hypoxia in an estuarine tidal mudflat. Mar Ecol Prog Ser 372:31-42.

Vanni M, Boros G, McIntyre PB (2013) When are fish sources vs. sinks of nutrients in lake ecosystems? Ecology 94: 2195-2206.

Villnäs A, Norkko J, Lukkari K, Hewitt J, Norkko A (2012) Consequences of increasing hypoxic disturbance on benthic communities and ecosystem functioning. PlosONE 7(10): e44920.

Villnäs A, Norkko J, Hietanen S, Josefson AB, Lukkari K, Norkko A (2013) The role of recurrent disturbances for ecoystem multifunctionality. Ecology 94:2275-2287.

Villnäs A, Hewitt J, Snickars M, Westerbom M, Norkko A (2018) Template for using biological trait groupings when exploring large-scale variation in seafloor multifunctionality. Ecol App 28: 78-94.

Weigel B, Blenckner T, Bonsdorff E (2016) Maintained functional diversity in benthic communities in spite of diverging functional identities. Oikos 125: 1421-1433.

Welsh DT (2003) It's a dirty job but someone has to do it: the role of marine benthic macrofauna in organic matter turnover and nutrient recycling to the water column. Chem Ecol 19: 321-342. 
Table 1. Subsets of biological traits and categories used for estimating sediment nutrient uptake, recycling and retention mediated by benthic communities at inner and outer coastal sites.

6 Table 2. Links between benthic trait groupings and processes describing their potential contribution to the coastal filter function.

Table 3. Monitoring data included in this study encompass inner and outer sites of five different coastal areas. Depth, salinity and oxygen content in bottom waters are based on measurements at the time of benthic sampling. ND=no data.

Table 4. The results of two-way crossed analyses of similarities (ANOSIM) describing differences in benthic abundance, biomass and trait composition between coastal areas and inner versus outer sites. The differences between inner and outer sites were further explored with one-way ANOSIM for each area. All traits were included, except for the carbon, nitrogen and phosphorous contents in the Roskilde Fjord (no data). RF: Roskilde Fjord, GG: Gulf of Gdansk, TA: Tvärminne archipelago, StA: St. Anna archipelago, UA: Umeå archipelago. 
1 Table 1.

2

\begin{tabular}{|c|c|c|c|}
\hline $\begin{array}{l}\text { Community } \\
\text { property }\end{array}$ & Trait & Trait modalities & Definition \\
\hline $\begin{array}{l}\text { Bioturbation } \\
\text { mode }\end{array}$ & $\begin{array}{c}\text { Environ- } \\
\text { mental } \\
\text { position }\end{array}$ & $\begin{array}{l}\text { no transport } \\
\text { surface modifier } \\
\text { tube dweller } \\
\text { biodiffuser } \\
\text { gallery diffuser } \\
\text { pelagic } \\
\text { epibenthic } \\
\text { infauna top } \\
\text { infauna bottom } \\
\text { very small } \\
\text { small } \\
\text { medium } \\
\text { large }\end{array}$ & $\begin{array}{l}\text { no transport or pelagic } \\
\text { modifies the sediment surface } \\
\text { builds and dwells in a tube } \\
\text { moves particles in random manner over short distances } \\
\text { excavates burrows, move particles by biodiffusion or directly } \\
\text { in the water column } \\
\text { on the sediment surface } \\
\text { in the uppermost } 2 \mathrm{~cm} \text { of the sediment } \\
\text { in deeper layers of the sediment }(>2 \mathrm{~cm}) \\
<0.001 \mathrm{~g} \\
0.001-0.01 \mathrm{~g} \\
0.01-0.1 \mathrm{~g} \\
0.1-1.0 \mathrm{~g}\end{array}$ \\
\hline Stability & Life span & $\begin{array}{l}\text { very small } \\
\text { small } \\
\text { medium } \\
\text { large } \\
<1 \mathrm{y} \\
1-2 \mathrm{y} \\
2-5 \mathrm{y} \\
5-10 \text { y or more }\end{array}$ & $\begin{array}{l}<0.001 \mathrm{~g} \\
0.001-0.01 \mathrm{~g} \\
0.01-0.1 \mathrm{~g} \\
0.1-1.0 \mathrm{~g}\end{array}$ \\
\hline $\begin{array}{c}\text { Energy and } \\
\text { nutrient } \\
\text { content }\end{array}$ & $\begin{array}{l}\text { Energy } \\
\text { content }\end{array}$ & $\begin{array}{l}\text { Low E } \\
\text { Medium E } \\
\text { High E } \\
\text { Low CNP } \\
\text { Medium CNP } \\
\text { High CNP }\end{array}$ & $\begin{array}{l}0-0.1 \mathrm{~kJ} \text { per individual } \\
0.1-1 \mathrm{~kJ} \text { per individual } \\
>1 \mathrm{~kJ} \text { per individual } \\
\mathrm{C}<1 \mathrm{mg}, \mathrm{N}<0.1 \mathrm{mg}, \mathrm{P}<0.01 \mathrm{mg} \text { per individual } \\
\mathrm{C}: 1-10 \mathrm{mg}, \mathrm{N}: 0.1-1 \mathrm{mg}, \mathrm{P}: 0.01-0.1 \mathrm{mg} \text { per individual } \\
\mathrm{C}>10 \mathrm{mg}, \mathrm{N}>1 \mathrm{mg}, \mathrm{P}>0.1 \mathrm{mg} \text { per individual }\end{array}$ \\
\hline
\end{tabular}




\section{Table 2.}

\begin{tabular}{|c|c|c|c|c|c|}
\hline Trait & $\begin{array}{c}\text { Trait } \\
\text { grouping }\end{array}$ & Activity & Process & $\begin{array}{l}\text { Function affecting } \\
\text { the coastal filter }\end{array}$ & References \\
\hline \multirow{6}{*}{ 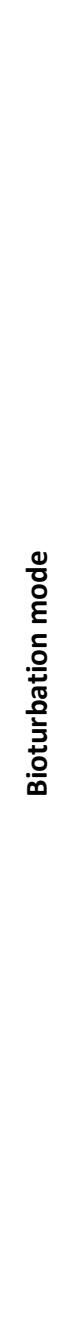 } & No transport & Pelagic. & $\begin{array}{l}\text { Activities primarily } \\
\text { affecting the water } \\
\text { column. }\end{array}$ & $\begin{array}{l}\text { No significant effect } \\
\text { on sediment nutrient } \\
\text { cycling. }\end{array}$ & \\
\hline & $\begin{array}{l}\text { Epibenthic } \\
\text { surface } \\
\text { modifiers }\end{array}$ & $\begin{array}{l}\text { Grazing on } \\
\text { microphytobentohs at } \\
\text { the sediment surface. }\end{array}$ & $\begin{array}{l}\text { Increase sediment } \\
\text { resuspension. }\end{array}$ & $\begin{array}{l}\text { Primarily affecting } \\
\text { sediment nutrient } \\
\text { cycling by regulating } \\
\text { primary producers. }\end{array}$ & $\begin{array}{l}\text { Sundbäck \& Miles 2000, } \\
\text { Andersen et al. 2002, } \\
\text { Orvain et al. } 2004\end{array}$ \\
\hline & $\begin{array}{l}\text { Small tube } \\
\text { dwellers }\end{array}$ & $\begin{array}{l}\text { Bioirrigation of } \\
\text { constructed tube during } \\
\text { restricted life-span, } \\
\text { enhance sediment } \\
\text { oxygen penetration. }\end{array}$ & & & $\begin{array}{l}\text { Hansen et al. 1988, Stief } \\
\& \text { Hölker 2006, Hölker } \\
\text { et al. 2015, Benelli et al. } \\
2018\end{array}$ \\
\hline & $\begin{array}{l}\text { Biodiffusers, } \\
\text { top sediment }\end{array}$ & $\begin{array}{l}\text { Enhance sediment } \\
\text { oxygen penetration to } \\
\text { the upper part of the } \\
\text { sediment. }\end{array}$ & $\begin{array}{l}\text { Promotes microbial } \\
\text { growth and activity, } \\
\text { mineralization rates, } \\
\text { nitrification-coupled- } \\
\text { denitrification, and } \\
\text { phosphate adsorption. }\end{array}$ & $\begin{array}{l}\text { Removal of nitrogen, } \\
\text { binding of } \\
\text { phosphorous. }\end{array}$ & $\begin{array}{l}\text { Tuominen et al. } 1999, \\
\text { Karlson et al. } 2007\end{array}$ \\
\hline & $\begin{array}{l}\text { Large } \\
\text { biodiffusers, } \\
\text { deep } \\
\text { sediment }\end{array}$ & $\begin{array}{l}\text { Enhance oxygen } \\
\text { penetration to deeper } \\
\text { parts of the sediment. }\end{array}$ & & & $\begin{array}{l}\text { Michaud et al. 2005, } \\
2006, \text { Karlson et al. } \\
2007\end{array}$ \\
\hline & $\begin{array}{l}\text { Medium- } \\
\text { sized gallery } \\
\text { diffusers }\end{array}$ & $\begin{array}{l}\text { Enhance sediment } \\
\text { oxygen penetration and } \\
\text { enlarges the oxic-anoxic } \\
\text { transition zone. }\end{array}$ & $\begin{array}{l}\text { Increases mineralisation } \\
\text { rates*, promotes } \\
\text { microbial growth and } \\
\text { activity, nitrificaiton- } \\
\text { coupled-denitrification, } \\
\text { and P adsorption. }\end{array}$ & $\begin{array}{l}\text { Removal of nitrogen, } \\
\text { binding of } \\
\text { phosphorous. }\end{array}$ & $\begin{array}{l}\text { Henriksen et al. 1983, } \\
\text { Hansen \& Kristensen } \\
\text { 1988, Sundby et al. } \\
\text { 1992, Norkko \& Reed et } \\
\text { al. } 2012\end{array}$ \\
\hline
\end{tabular}


1 Table 2. Continued.

2

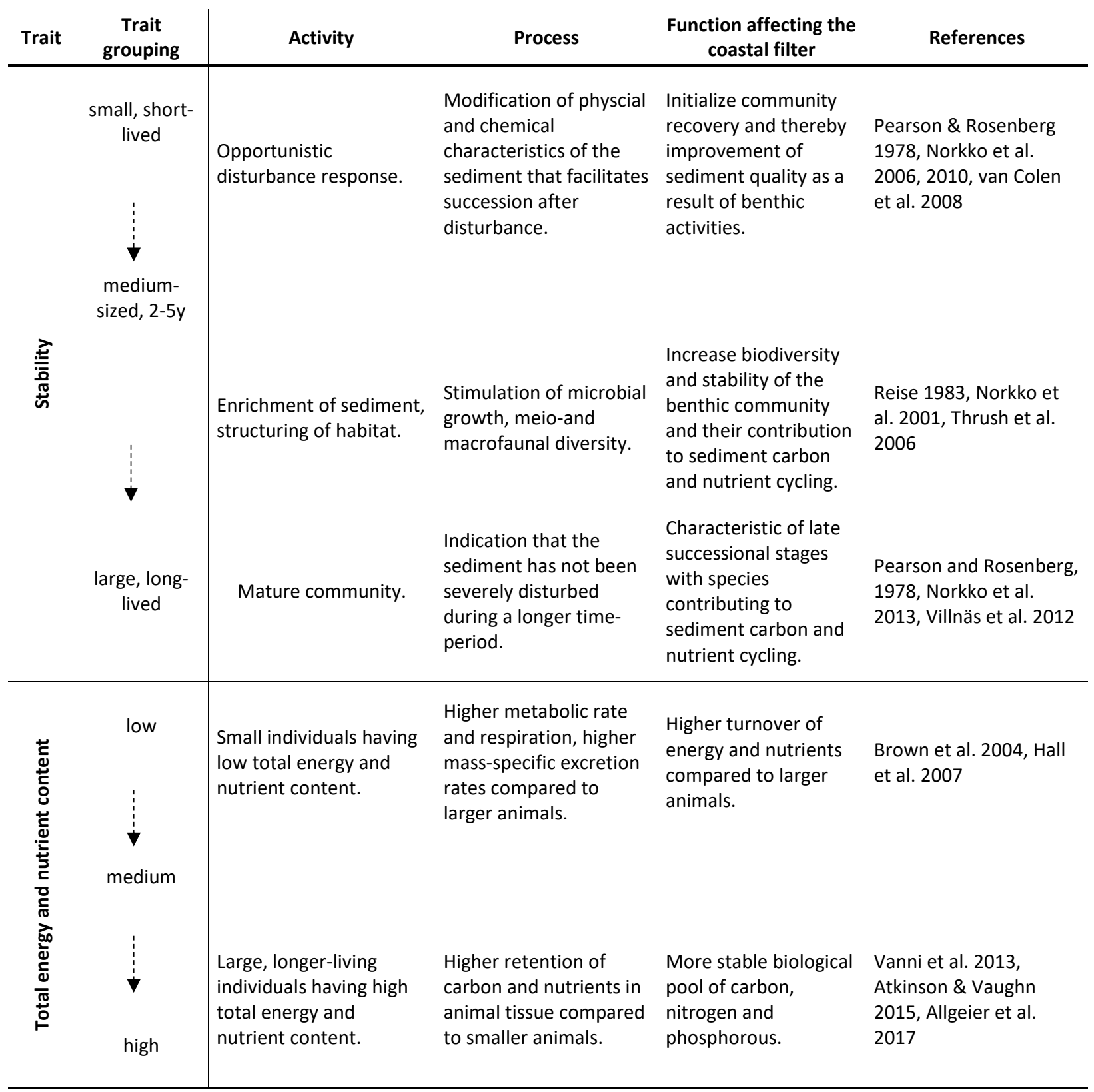

* medium-sized gallery diffusers have also been shown to bury fresh organic material (Nordström et al. 2006, Josefson et al. 2012), which could slow down degradation rates. 
Table 3.

\begin{tabular}{|c|c|c|c|c|c|c|c|c|c|c|c|c|c|c|}
\hline \multirow{2}{*}{ Area } & \multirow{2}{*}{ Site } & \multirow{2}{*}{$\begin{array}{l}\text { Stat- } \\
\text { ions }\end{array}$} & \multirow{2}{*}{ Year } & \multirow{2}{*}{ Season } & \multirow{2}{*}{$\begin{array}{l}\text { Area } \\
\left(\mathrm{km}^{2}\right)\end{array}$} & \multirow{2}{*}{$\begin{array}{l}\text { Res. } \\
\text { time }\end{array}$} & \multicolumn{2}{|c|}{ Depth } & \multicolumn{2}{|c|}{ Salinity } & \multicolumn{2}{|c|}{$\mathrm{O}_{2}(\mathrm{ml} / \mathrm{l})$} & \multirow{2}{*}{$\begin{array}{l}\text { Eutrophication } \\
\text { classification* }\end{array}$} & \multirow{2}{*}{$\operatorname{Basin}(s)$} \\
\hline & & & & & & & avg. & std & avg. & std & avg. & std & & \\
\hline \multirow{2}{*}{$\begin{array}{l}\text { Roskilde } \\
\text { Fjord }\end{array}$} & Inner & 5 & 2004 & Spring & 123 & 90 & 4.4 & 1.9 & 17.6 & 10.4 & 5.8 & 15.0 & $\begin{array}{l}\text { Higher } \mathrm{N} \\
\text { loadings }\end{array}$ & Roskilde N \\
\hline & Outer & 5 & 2004 & Spring & 255 & 46 & 5.8 & 3.7 & 18.9 & 12.5 & 5.9 & 9.3 & $\begin{array}{l}\text { Lower } \mathrm{N} \\
\text { loadings }\end{array}$ & Isefjord \\
\hline \multirow{2}{*}{$\begin{array}{l}\text { Gulf of } \\
\text { Gdansk }\end{array}$} & Inner & 8 & $\begin{array}{l}2005- \\
2015\end{array}$ & Autumn & 103 & 38 & 4.8 & 2.7 & 6.8 & 0.4 & 7.0 & 0.7 & Bad/Poor & $\begin{array}{l}\text { Inner PB, } \\
\text { outer coast }\end{array}$ \\
\hline & Outer & 6 & 2010 & Autumn & 257 & $7-30$ & 36.8 & 15.9 & 7.1 & 0.6 & 7.8 & 1.1 & Moderate & $\begin{array}{l}\text { Outer PB, } \\
\text { GG }\end{array}$ \\
\hline \multirow{2}{*}{ St. Anna } & Inner & 21 & 2012 & Spring & 46 & $\begin{array}{l}10- \\
39^{1} \\
>40^{2}\end{array}$ & 20.0 & 9.7 & \multicolumn{2}{|c|}{ 4.1-6.4 } & ND & ND & Bad/Poor & $\begin{array}{l}\text { Inre } \\
\text { Slätbaken², } \\
\text { Trännöfjärd }^{1}\end{array}$ \\
\hline & Outer & 14 & 2012 & Spring & 63 & $>40$ & 16.4 & 5.1 & 6.2 & 0.1 & 9.9 & 0.4 & Moderate & Kärrfjärden \\
\hline \multirow{2}{*}{$\begin{array}{l}\text { Tvär- } \\
\text { minne }\end{array}$} & Inner & 24 & 2012 & Autumn & 80 & ND & 18.4 & 7.6 & 5.8 & 0.1 & 7.5 & 1.3 & Poor & Dragsvik, Box \\
\hline & Outer & 15 & 2012 & Autumn & 500 & ND & 34.6 & 6.9 & 6.0 & 0.1 & 6.5 & 0.6 & Moderate & $\begin{array}{l}\text { Outer } \\
\text { Storfjärden, } \\
\text { Hankoniemi }\end{array}$ \\
\hline \multirow{2}{*}{ Umeå } & Inner & 10 & 2006 & Spring & 16 & $10-39$ & 7.8 & 4.4 & 2.8 & 0.8 & 6.2 & 2.0 & Moderate & Österfjärden \\
\hline & Outer & 12 & 2006 & Spring & 1125 & $0-9$ & 25.5 & 12.8 & 4.7 & 0.6 & 7.3 & 0.6 & Good & $\begin{array}{l}\text { Fjärdgrunds- } \\
\text { omr., the } \\
\text { Quark }\end{array}$ \\
\hline
\end{tabular}

Information regarding area, volume, residence time and eutrophication classification were available from Josefson \& Hansen (2004), the VISS database (http://viss.lansstyrelsen.se/), the SYKE HERTTA register (https://www.syke.fi/enUS/Open_information), Andrulewicz et al. (2004) and Kruk-Dowgiałło \& Szaniawska (2008).The eutrophication assessment generally follows the WFD classification. For the Roskilde Fjord, only information on nutrient loadings were available (cf. Josefson \& Hansen 2004). PB: Puck Bay, GG: Gulf of Gdansk. 
1 Table 4.

2

\begin{tabular}{l|cccccc}
$\begin{array}{l}\text { Two way } \\
\text { crossed }\end{array}$ & $\begin{array}{c}\text { Abundance } \\
\text { Global } \mathbf{R}\end{array}$ & $\mathbf{p}$ & Global $\mathbf{R}$ & $\mathbf{p}$ & Global $\mathbf{R}$ & $\mathbf{p}$ \\
\hline Area & 0.68 & 0.0001 & 0.61 & 0.0001 & 0.483 & 0.0001 \\
Inner vs outer & 0.56 & 0.0001 & 0.42 & 0.0001 & 0.418 & 0.0001 \\
Pair-wise area & $\mathbf{R}$ & $\mathbf{p}$ & $\mathbf{R}$ & $\mathbf{p}$ & $\mathbf{R}$ & $\mathbf{p}$ \\
RF, GG & & & & & & \\
RF, TA & 0.84 & 0.0001 & 0.81 & 0.0001 & 0.28 & 0.0080 \\
RF, UA & 0.99 & 0.0001 & 0.97 & 0.0001 & 0.74 & 0.0001 \\
RF, StA & 0.94 & 0.0001 & 0.85 & 0.0001 & 0.33 & 0.0030 \\
GG, TA & 0.98 & 0.0001 & 0.83 & 0.0001 & 0.48 & 0.0002 \\
GG, UA & 0.90 & 0.0001 & 0.80 & 0.0001 & 0.64 & 0.0001 \\
GG, StA & 0.78 & 0.0001 & 0.72 & 0.0001 & 0.51 & 0.0001 \\
TA, UA & 0.77 & 0.0001 & 0.57 & 0.0001 & 0.51 & 0.0001 \\
TA, StA & 0.57 & 0.0001 & 0.58 & 0.0001 & 0.64 & 0.0001 \\
UA, StA & 0.68 & 0.0001 & 0.58 & 0.0001 & 0.63 & 0.0001 \\
One way & 0.32 & 0.0005 & 0.36 & 0.0001 & 0.18 & 0.0050 \\
RF & & & inner vs outer & & \\
GG & 0.80 & 0.0080 & 0.77 & 0.0080 & 0.29 & 0.0630 \\
TA & 0.57 & 0.0003 & 0.53 & 0.0003 & 0.41 & 0.0040 \\
StA & 0.63 & 0.0001 & 0.37 & 0.0001 & 0.44 & 0.0001 \\
UA & 0.43 & 0.0001 & 0.41 & 0.0001 & 0.40 & 0.0001 \\
& 0.54 & 0.0003 & 0.56 & 0.0001 & 0.47 & 0.0002
\end{tabular}


Figure 1. Map describing the different study areas along the Baltic Sea gradient. UA: Umeå archipelago, TA: Tvärminne archipelago, St. A: St. Anna archipelago, GG: Gulf of Gdansk, RF: Roskilde Fjord. Note the different scales. Inner sites are represented by dots, outer sites by triangles.

Figure 2. The A) energy content (kJ), B) total carbon, C) nitrogen and D) phosphorus content per species related to the average wet weight of benthic fauna in the Tvärminne archipelago region. Different symbols mark trait categories representing high, medium and low energy and nutrient content of a species. Note that the axes are log transformed.

Figure 3. Differences in A) bioturbation mode, B) stability and C) energy, carbon and nutrient content between inner (circles) vs outer (triangles) sites for the Tvärminne archipelago. The upper graph represents the principal coordinate of each site along the first PCO axis. The lower graph shows the contribution of each trait subset (\%) to total abundance at a site. Abundance (dotted line) is expressed as $\%$ of the maximum abundance measured in the area. Sites are ordered to describe a gradient from their main source of freshwater discharge, in the direction of the arrow.

Figure 4. Differences in benthic bioturbation between inner (circles) vs outer (triangles) sites for the different coastal areas. The upper graph represents the principal coordinate of each sites along the first PCO axis, except for the Umeå archipelago, where a CAP analysis was performed. For explanation of the lower graph, see Fig. 3.

Figure 5. Differences in benthic stability between inner (circles) vs outer (triangles) sites for the different coastal areas. The upper graph represents the principal coordinate of each sites along the first PCO axis, except for the Umeå archipelago, where a CAP analysis was performed. For explanation of the lower graph, see Fig. 3. 
1 Figure 6. For the Roskilde Fjord, differences in benthic community energy content between inner 2 (circles) vs outer (triangles) sites are depicted, while graphs for the Gulf of Gdansk, St. Anna and 3 Umeå archipelagos represent differences in benthic faunal energy as well as C, N, P contents. The 4 upper graph represents the principal coordinate of each sites along the first PCO axis. For 5 explanation of the lower graph, see Fig. 3. 
$1 \quad$ Figure 1.

2
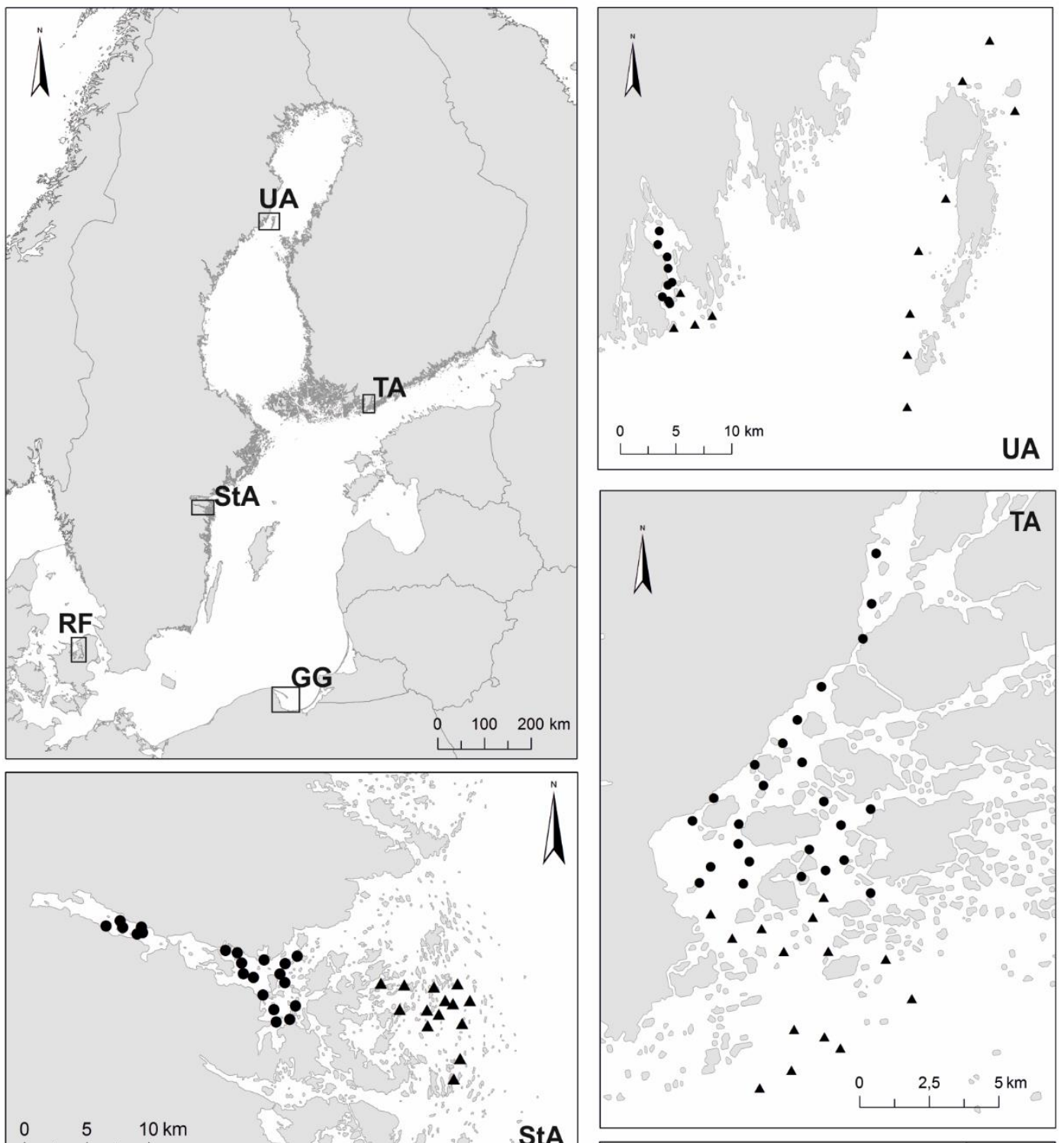

$\begin{array}{lll}0 & 5 & 10 \mathrm{~km}\end{array}$

$88^{\circ}$
$88^{\circ}$

$\because$ Â

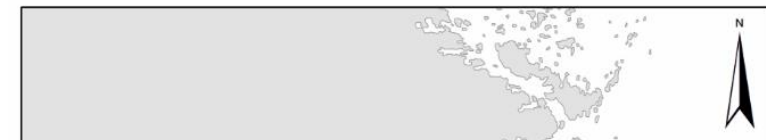

.8
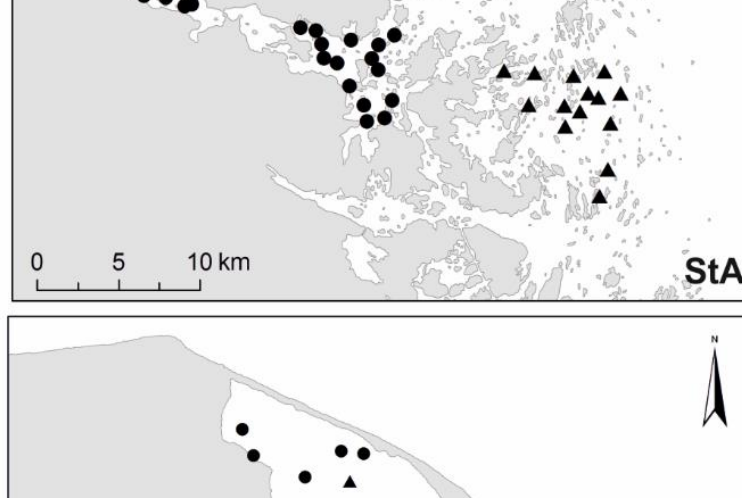

$0 \quad 510 \mathrm{~km}$

GG

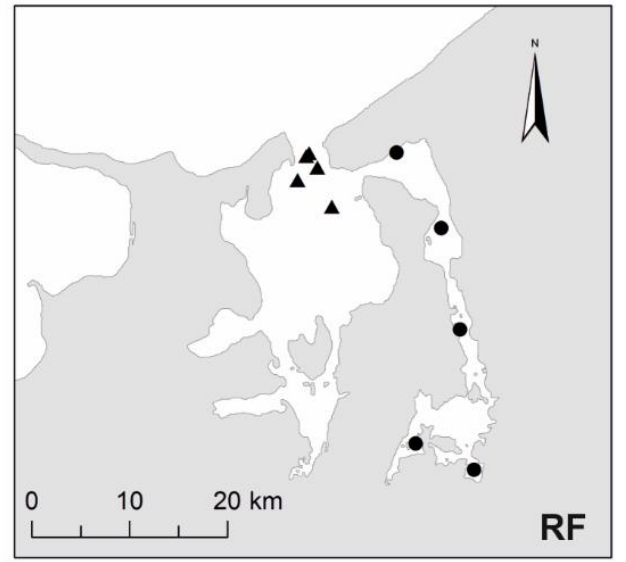


$1 \quad$ Figure 2.

2

3
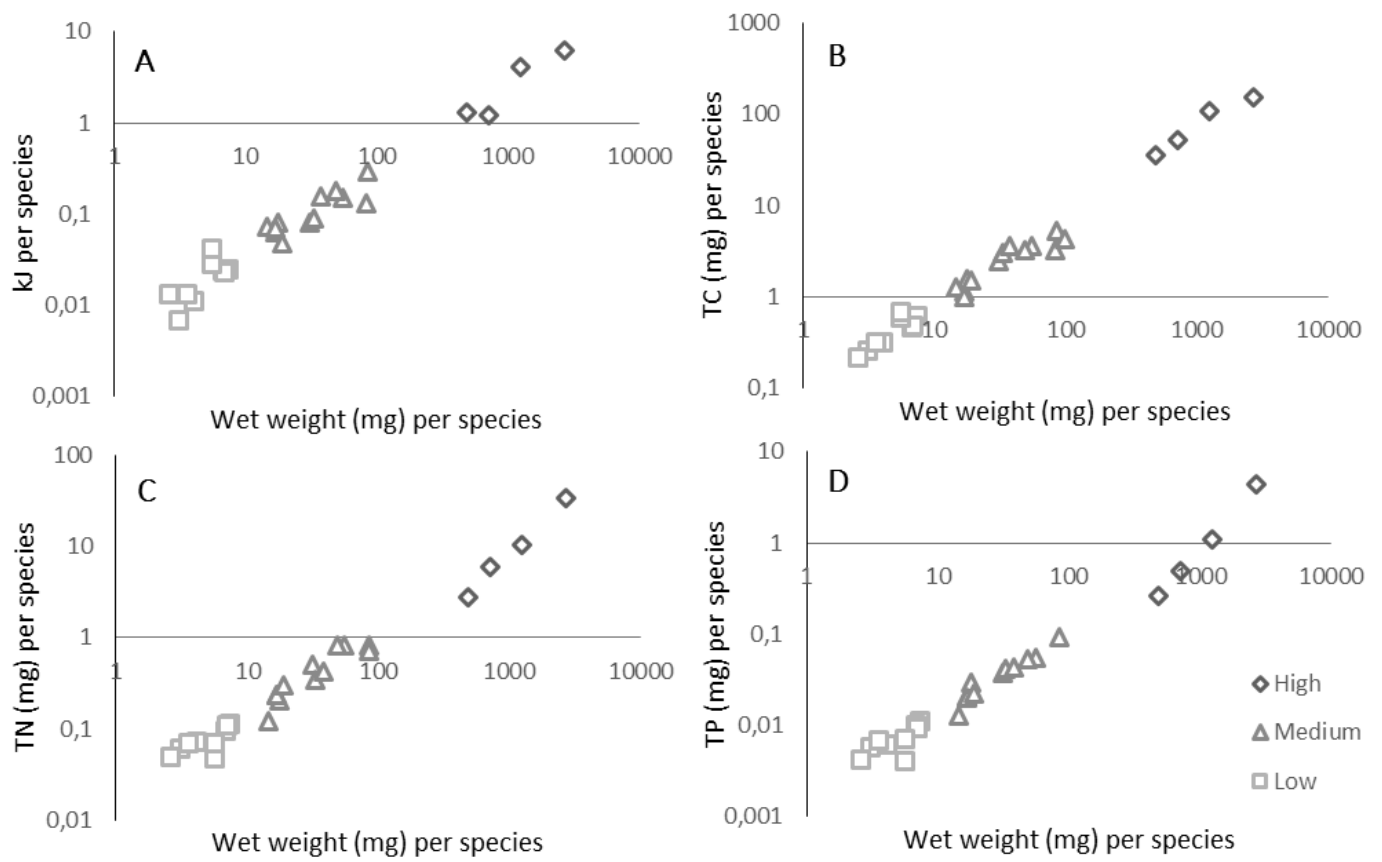

4

5

6

7

8

9

10

11

12

13

14

15

16

17

18

19

20

(41) 
1 Figure 3.

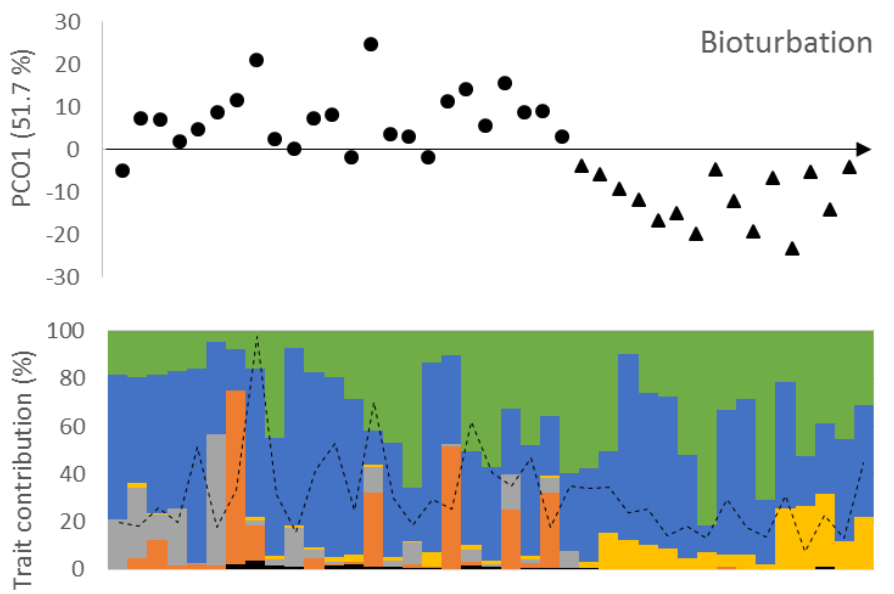

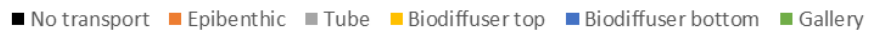
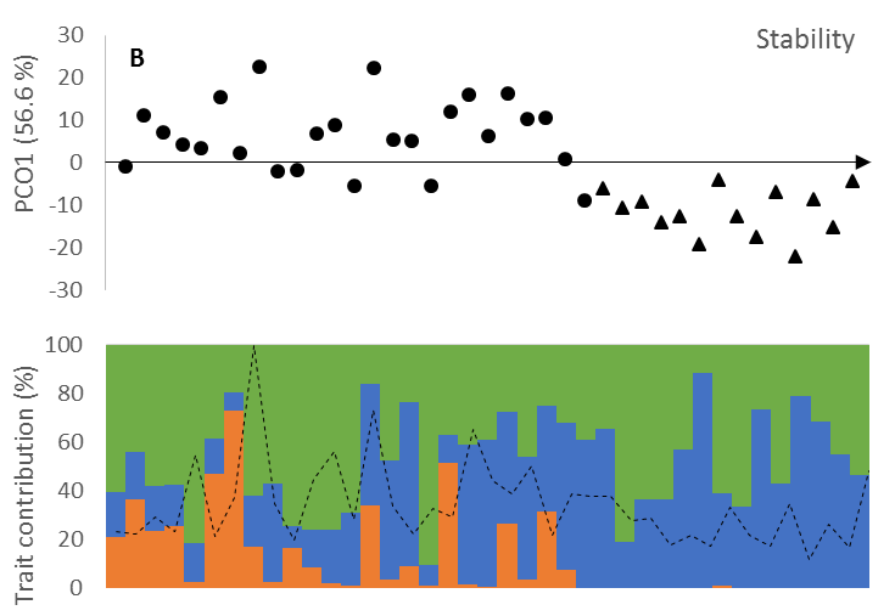

घ, $<2 y \quad m, 2-5 y \quad \square \mathrm{l},>5 \mathrm{y}$

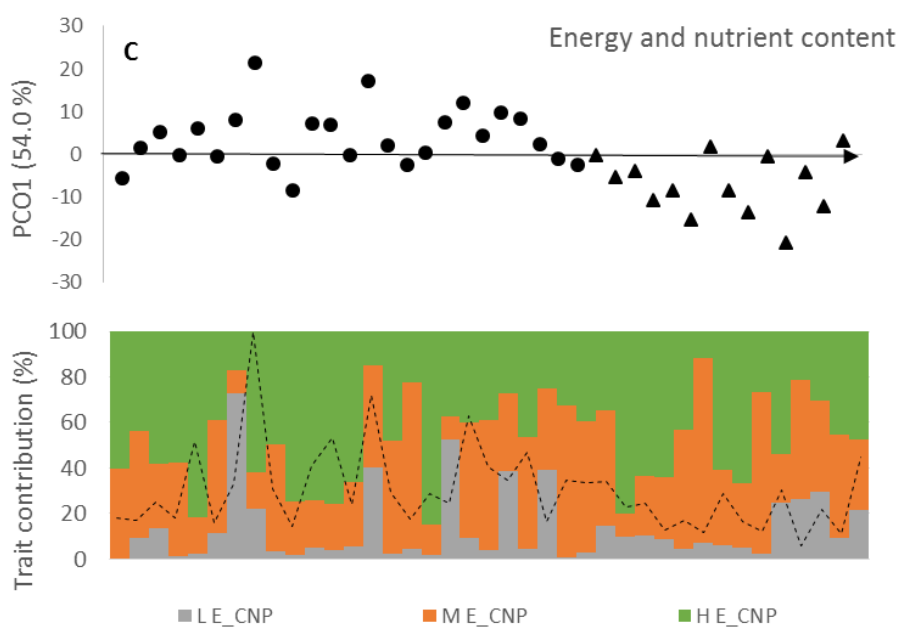


1 Figure 4.

2
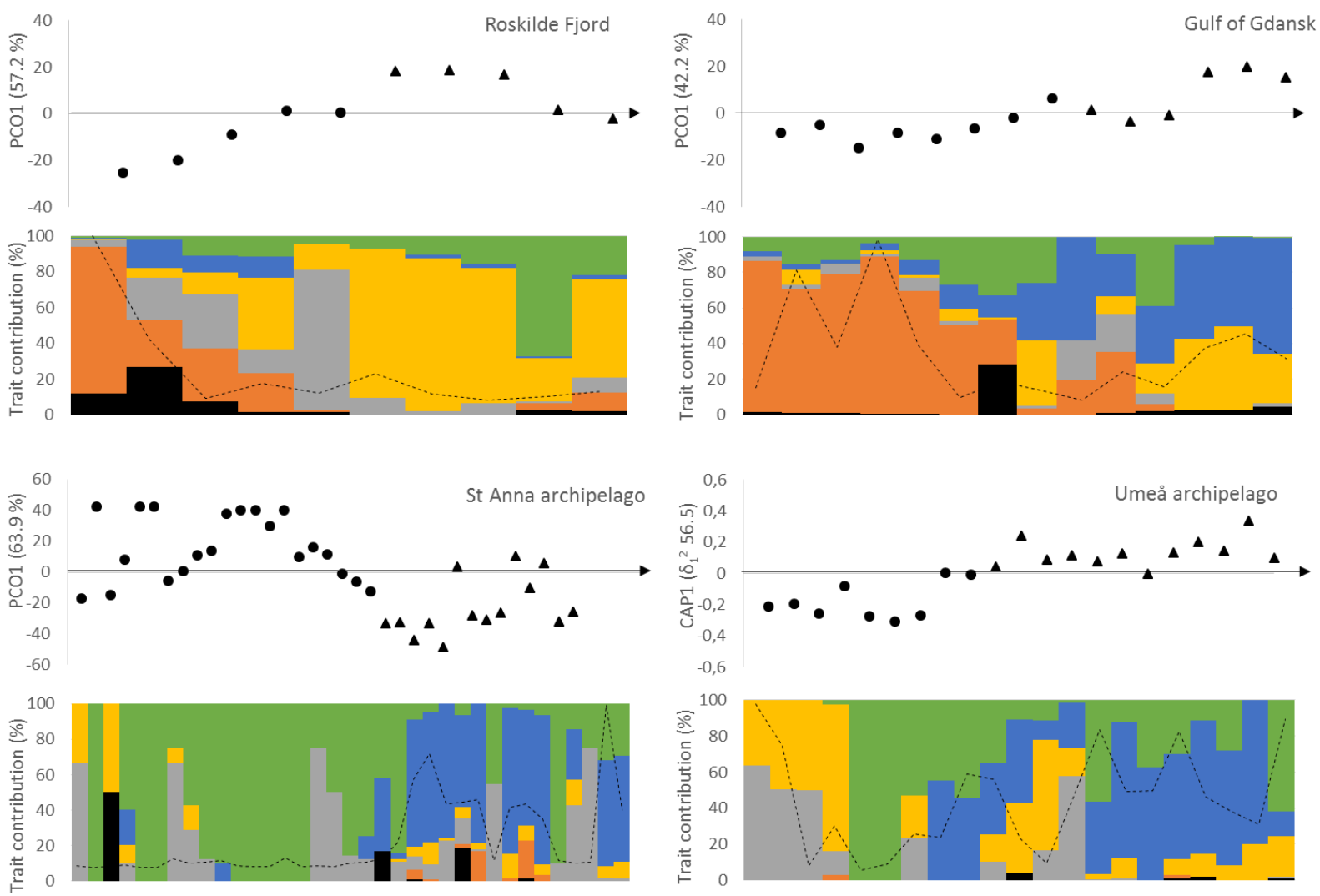

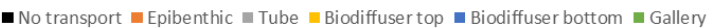

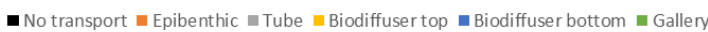


$1 \quad$ Figure 5.

2
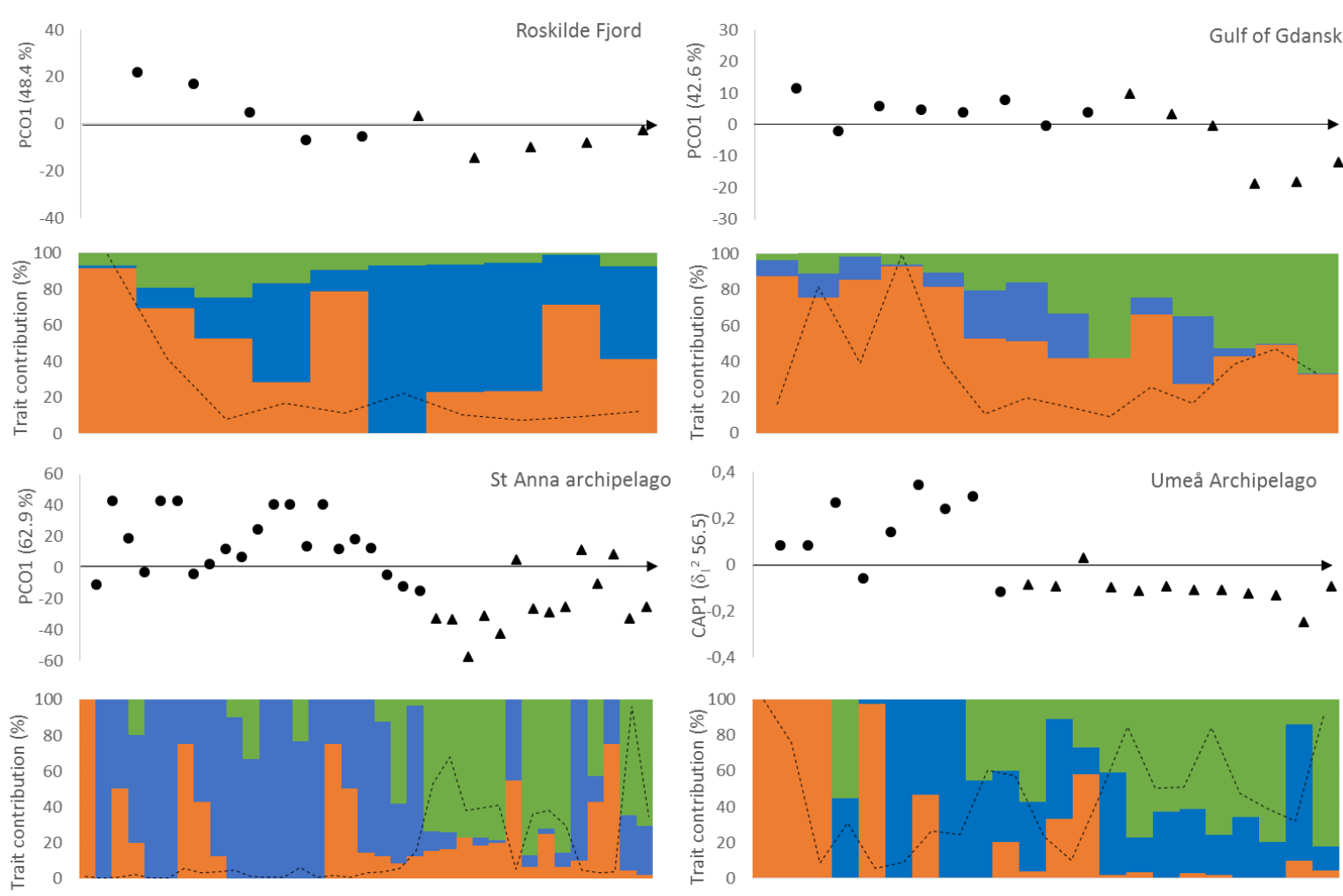

3

= $\mathrm{s},<2 \mathrm{y}=\mathrm{m}, 2-5 \mathrm{y}=\mathrm{l},>5 \mathrm{y}$

- $\mathrm{s},<2 \mathrm{y}=\mathrm{m}, 2-5 \mathrm{y} \quad \mathrm{I} \mathrm{l},>5 \mathrm{y}$ 
$1 \quad$ Figure 6.

2
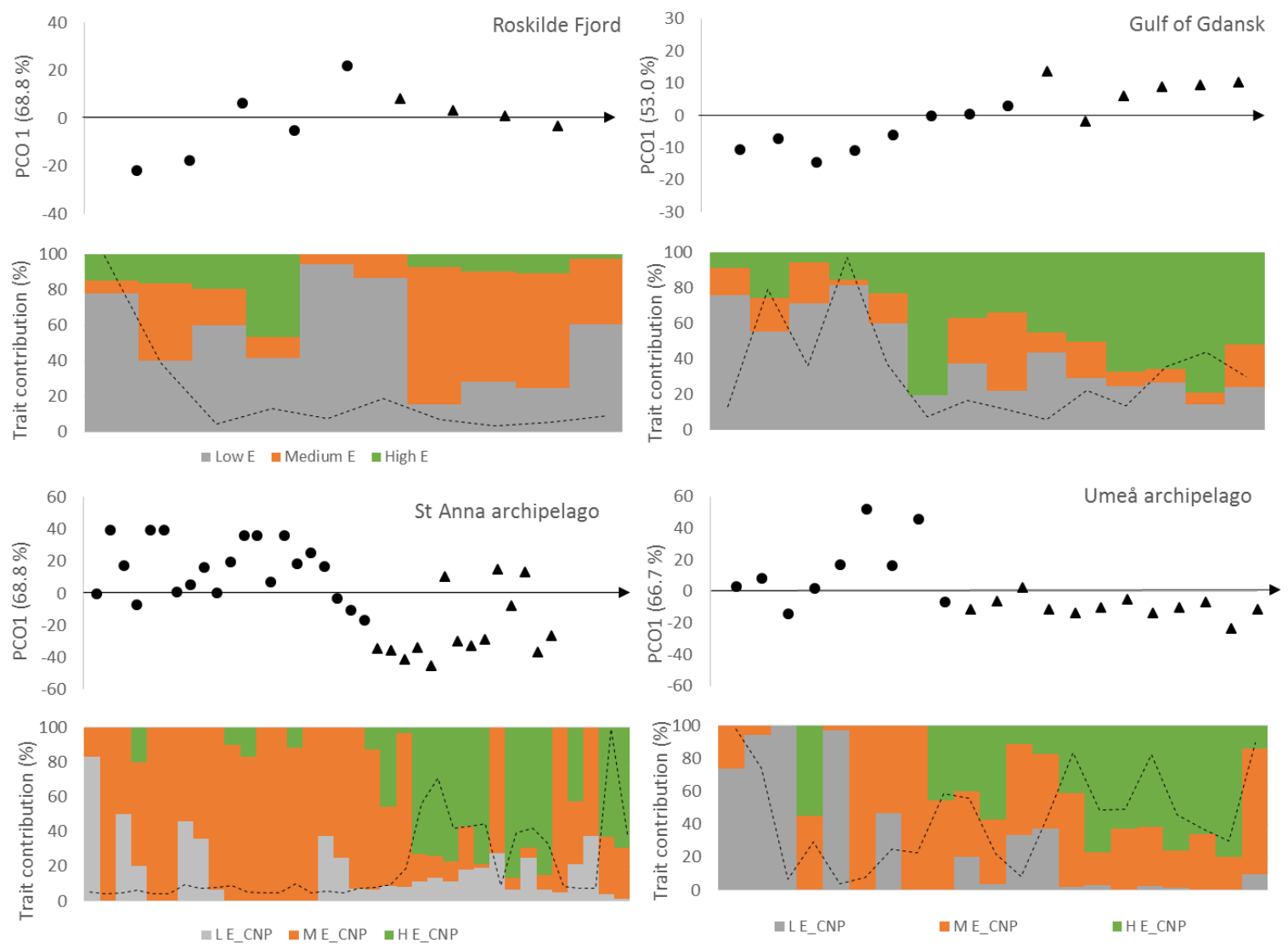

3 